\title{
Protozoan and metazoan zooplankton-mediated carbon flows in nutrient-enriched coastal planktonic communities
}

\author{
Yngvar Olsen $^{1, *}$, Tom Andersen ${ }^{2}$, Ingrid Gismervik ${ }^{2}$, Olav Vadstein ${ }^{3}$ \\ ${ }^{1}$ Trondhjem Biological Station, Department of Biology, and ${ }^{3}$ Department of Biotechnology, \\ Norwegian University of Science and Technology, 7491 Trondheim, Norway \\ ${ }^{2}$ Department of Biology, University of Oslo, PO Box 1066 Blindern, 0316 Oslo, Norway
}

\begin{abstract}
The objective of the present study was to study the dynamics of protozoan and metazoan zooplankton food webs in coastal NE Atlantic waters exposed to variable nutrient input. Data were derived from a mesocosm experiment ( 7 units, $40 \mathrm{~m}^{3}, 12 \mathrm{~m}$ deep) receiving variable nutrient input. The food web included 3 autotrophic groups based on size, and 4 functional heterotrophic groups mainly based on trophic position. Inverse modelling was used to construct networks of carbon flows for the planktonic food web. Heterotrophic nanoplankton, microplankton and mesoplankton (HNP, CIL and COP, respectively) were found to be equally important contributors to grazing and carbon release during undisturbed summer situations. The release of dissolved organic carbon by zooplankton was comparable to that of phytoplankton. Autotrophic food was generally more important for zooplankton than heterotrophic (mean 75\%). Assimilation and growth efficiencies (AE and GE, respectively) of zooplankton groups in undisturbed situations were in the range of 33 to $69 \%$ and 10 to $41 \%$, respectively. Values were inversely related to gross primary production (GPP). Sedimentation rates of carbon were low. High nutrient input rates increased food availability and most CIL and COP carbon flows. HNP did not respond, and neither did its food, that is, bacteria and picoautotrophs. The response in biomass was generally lower than that for the flows. Values of AE and GE of the zooplankton during high nutrient input and food availability varied between 11 and $29 \%$ and 5.7 and $19 \%$, respectively, and throughout were lower than at low nutrient input. The sedimentation rate of particulate carbon increased strongly, resulting in an enhanced organic input rate in deep water.
\end{abstract}

KEY WORDS: Metazoan · Protozoan · Coastal eutrophication · Assimilation efficiency · Growth efficiency $\cdot$ Carbon feeding rates $\cdot$ Carbon release rates

- Resale or republication not permitted without written consent of the publisher

\section{INTRODUCTION}

It is well established that primary production of marine phytoplankton communities is a dynamic variable that depends on nutrient supply (e.g. Cloern 2001). Zooplankton grazing affects primary production only moderately, whereas phytoplankton biomass is more strongly affected (Olsen et al. 2006). Research efforts have addressed how, and with what level of efficiency, grazing zooplankton groups are able to exploit primary production, and also enable the transfer of this production to higher trophic levels. The functional role of zooplankton groups, their growth efficiencies and their specific growth rates are important issues (Gismervik et al. 1996, Montagnes 1996, Straile 1997, Hirst et al.
2003). Recent studies have examined the ability of zooplankton to mutually interact and control biomass at lower trophic levels (Sommer \& Stibor 2002, Stibor et al. 2004, Vadstein et al. 2004). Recent research activity has also contributed to a growing understanding of the role of zooplankton and planktonic bacteria in inhibiting by mitigating the efffects of phytoplankton blooms following enhanced nutrient input to coastal seas (Gismervik et al. 1996, Stibor et al. 2004, Olsen et al. 2006). The revised understanding of the role of planktonic bacteria (Azam et al. 1983) has spawned a number of studies on abundance, carbon transport efficiency and trophic interactions between protozoan grazers, their food and their predators (del Giorgio \& Cole 1998, Sherr \& Sherr 2002, Tanaka \& Rassoulzadegan 2002). 
The knowledge gained from studies such as these should be considered in ecosystem simulation models. The motivation is to obtain a more fundamental and mechanistic understanding of trophic interactions and the highly variable energy conversion efficiencies found in the planktonic food web (Straile 1997). Such knowledge is needed to establish more mechanistic and robust ecological models of marine biological resources that, in turn, are vital for ecosystem-based management of these resources.

Planktonic food webs are complex, with a large and variable number of species and trophic levels, and dynamic interactions between trophic levels. A simplification of this complexity may be achieved by assigning organisms with comparable roles to the same functional group. Nevertheless, even in a simplified planktonic food web, the number of fluxes connecting the components will be larger than what can be practicably measured directly. External flows (e.g. primary production, community respiration, sedimentation) are normally easier to measure than the internal fluxes between food web components (e.g. grazing, egestion, exudation), and only a few of the rates and processes involved can normally be measured simultaneously. The inverse method for flow network reconstruction described by Vézina \& Platt (1988) allows the estimation of a complete set of flow rates in relatively complex food webs. The method has been successfully applied to carbon and nutrient flows in several planktonic food webs (Jackson \& Eldridge 1992, Stone et al. 1993, Vézina \& Pace 1994, Lyche et al. 1996, Olsen et al. 2006). An appropriate inverse model represents a relatively unbiased and sophisticated means to establish mass balance of carbon between the components of the food web and its surroundings.

Normal ecological modelling is based on initial state variables (concentrations and biomass) and parameters for the processes that describe the behaviour of the system, and all fluxes are calculated based on these state variables and parameters. Common outputs for ecological models are simulated time series of concentrations, biomasses and flows. Inverse modelling is almost the opposite: the input includes measured time series of biomasses and concentrations, some measured flows, and general information about the trophic position and physiological constraints of the organisms that dominate the functional components. The output of inverse modelling is a complete set of average flows for the period, i.e. a flow network.

The objective of the present paper was to study the magnitude and the dynamics of protozoan and metazoan zooplankton-mediated carbon flows in coastal plankton communities exposed to variable nutrient input. In particular, we wanted to characterise this flow pattern under normal, undisturbed summer conditions

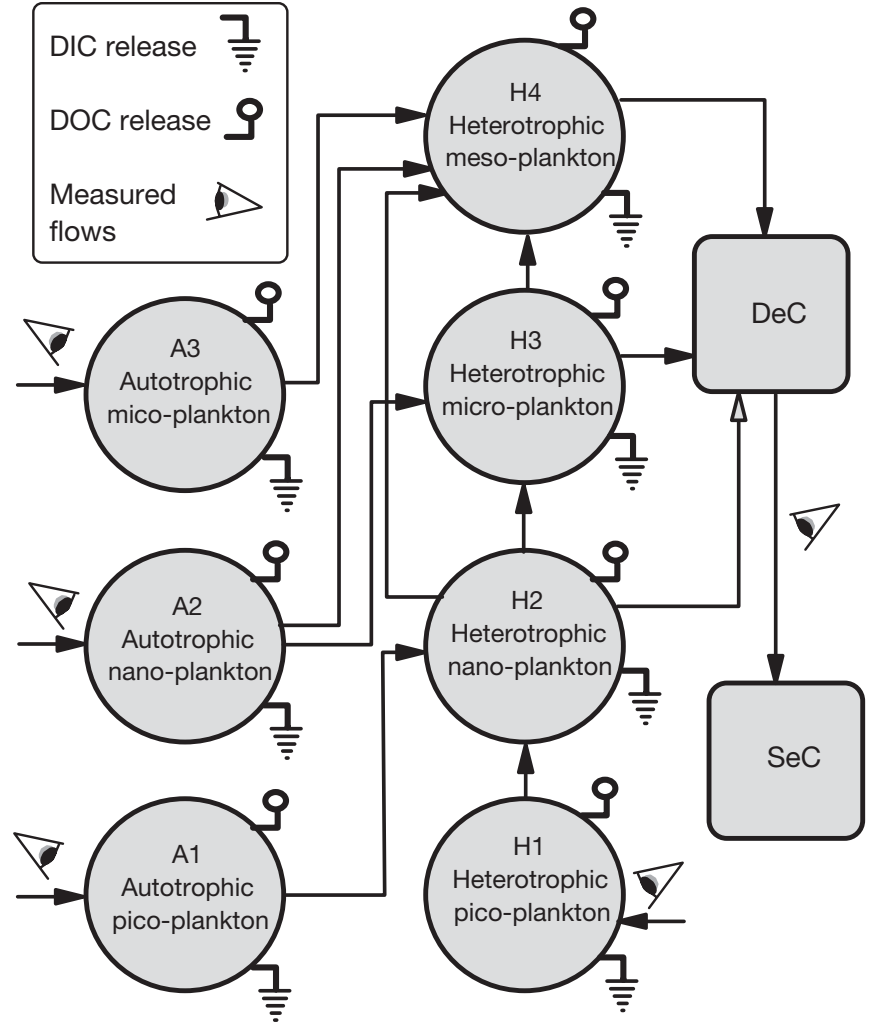

Fig. 1. Functional groups and main carbon flows of the planktonic food web used to estimate carbon-mediated zooplankton flows by inverse modelling. Arrows indicate uptake or feeding flows - dissolved inorganic C (DIC) release originates from respiration; dissolved organic $\mathrm{C}$ (DOC) release originates from sloppy feeding, excretion, exudation, and defecation; DeC (detrital particulate organic C) originates from sloppy feeding, defecation and mortality. Measured flows are indicated specifically. SeC: sedimentary C

and during high nutrient input. Data were derived from a comprehensive mesocosm experiment designed to supply suitable data sets for inverse modelling of carbon flows. The food web components were assigned to 3 functional autotrophic groups based on size and 4 heterotrophic groups based on trophic position and size (Fig. 1). We used inverse modelling (Vézina \& Platt 1988) to reconstruct the carbon flows in the coastal planktonic food web investigated, and the established flow networks involved autotrophic, bacterial and zooplankton flows.

\section{MATERIALS AND METHODS}

Experimental design and operation. Seven large mesocosms (12 m deep, volume $38 \mathrm{~m}^{3}$ ) were suspended in a tidally driven lagoon system on the west coast of central Norway (Hopavågen, $70^{\circ} 52^{\prime} \mathrm{N}$, 
$52^{\circ} 71^{\prime}$ E) (chlorophyll a concentration: 1 to $3 \mu \mathrm{g} \mathrm{l}^{-1}$, water residence time: 7 to $10 \mathrm{~d}$ ). Pelagic waters containing the natural plankton community were enclosed by sinking the mesocosms to $12 \mathrm{~m}$ depth and then carefully lifting the top part to the surface. The mesocosms were moored at the surface with a distance between units to minimise shading and to secure efficient mixing through wave exposure of mesocosm walls. The sampled water column did not stratify during the experiment. The temperature and salinity in the mesocosms were 15 to $16^{\circ} \mathrm{C}$ and 29 to $32 \mathrm{ppt}$, respectively. Mean photosynthetically active radiation (PAR) values varied between 100 and $800 \mu \mathrm{mol} \mathrm{m}{ }^{-2} \mathrm{~s}^{-1}$, mainly dependent on natural irradiance.

The experiment was a single-factor experiment (variable nutrient dose, balanced N:Si:P) run for $18 \mathrm{~d}$ (19 August to 5 September 1997). The nutrient doses added (Table 1) formed an exponential series, and the intention was that the highest dose should result in some degree of saturation of the autotrophic response. To Mesocosm 3, nutrients were added in amounts and proportions comparable to the average natural supply to the lagoon system, estimated based on measurements of P sedimentation from euphotic waters during June to September 1996, using common sedimentation techniques (authors' unpubl. data).

A freshly prepared nutrient mixture made from stock solutions was added daily after sampling. This was done by lowering an open-ended $10 \mathrm{~m}$ plastic tube down into the mesocosms. The tube was then filled from the top with the mixed nutrient solution (with a volume equal to that of the tube). The nutrient solution replaced the seawater in the tube, which was then emptied by lifting it to the surface. This method secured immediate and efficient distribution and mixing of the nutrients.

Sampling and biomass determination. Integrated water samples (0 to $10 \mathrm{~m}$ ) were collected daily using a Ramberg sampler (2 m length, 4.21 volume). Water samples were transferred to 251 light-protected containers in the morning (6.00 to 8.30 a.m.) and brought to the laboratory. Samples of plankton and chemical components were taken from these containers, whereas mesozooplankton was sampled separately.
Samples for measurement of primary production and ${ }^{3} \mathrm{H}$-thymidine uptake in bacteria were taken from the container immediately after sampling.

Samples of bacteria, autotrophic picoplankton (i.e. mainly picocyanobacteria) and heterotrophic nanoflagellates (HNF) $(100 \mathrm{ml})$ were taken each second day, fixed with $0.3 \mathrm{ml}$ of $0.15 \mathrm{~mol} \mathrm{l}^{-1}$ EDTA solution and thereafter preserved with $10 \mathrm{ml}$ of $10 \%$ glutaraldehyde ( $1 \%$ final concentration). Cells were filtered onto black polycarbonate filters (Millipore, $25 \mathrm{~mm}$ diameter, $0.2 \mu \mathrm{m}$ pore), and a Zeiss Axioplan 2 epifluorescence microscope was used for enumeration and sizing. The epifluorescence microscope was connected to a Power Macintosh computer, and an image-processing program (IP Lab) was used for enumeration and sizing of cells. A green waveband filter (520 to $560 \mathrm{~nm}$ ) was used for counting of autotrophic picoplankton, and a minimum of 4 squares and 200 cells were counted. Samples for enumeration of bacteria and HNF were stained with DAPI (4,6-diamidino-2-phenylindole) just after sampling (Porter \& Feig 1980). Cells of bacteria were counted and measured under UV light, whereas HNF were counted and measured by switching between the UV and the blue excitation. This method allowed separation of autotrophic and heterotrophic flagellates based on differential autofluorescence responses. Biovolumes of the cells were estimated based on simple geometrical formulas, and carbon biomass was calcu-

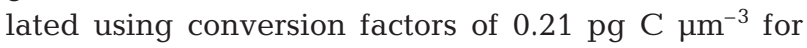

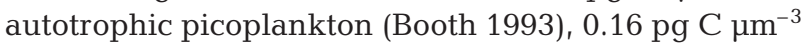
for bacteria (Vadstein \& Olsen 1989) and 0.22 pg C $\mu \mathrm{m}^{-3}$ for HNF (Børsheim \& Bratbak 1987).

Samples of phytoplankton and microzooplankton were taken from containers every second day and preserved with acidic Lugol's iodine added in 1 and $2 \%$ final concentration, respectively. Samples were counted, and sizes were measured using 10 or $50 \mathrm{ml}$ Utermöhl chambers. Cell volumes were calculated using simple geometrical formulas. Carbon biomass of phytoplankton was estimated based on bio-volume and group-specific regressions (Strathmann 1967). Ciliate biomass was estimated using a factor of $0.19 \mathrm{pg}$ $\mathrm{C} \mathrm{\mu m}^{-3}$ (Putt \& Stoecker 1989, see details in Gismervik et al. 2002).

Table 1. Daily nutrient addition rates used in the experiment $\left(L_{N}, L_{\mathrm{P}}\right.$ and $L_{\mathrm{Si}}$, for nitrogen, phosphorus and silicon, repectively, in $\mu \mathrm{g} \mathrm{l}^{-1} \mathrm{~d}^{-1}$ ). Elemental ratio for N:Si:P was 16:16:1, and doses from Mesocosms 2 to 7 increased exponentially (factor 1.7). Mesocosm 3 received $\mathrm{N}$ and $\mathrm{P}$ doses similar to those estimated for the natural system. $\mathrm{N}$ was added as $\mathrm{NH}_{4} \mathrm{NO}_{3}\left(50 \% \mathrm{NO}_{3}^{-}\right.$and $50 \%$ $\mathrm{NH}_{4}{ }^{+}$; $\mathrm{P}$, as $\mathrm{Na}_{2} \mathrm{HPO}_{4}$; and $\mathrm{Si}$, as $\mathrm{SiO}_{2}$

\begin{tabular}{|lccccccc|}
\hline Nutrient addition & Meso. 1 & Meso. 2 & Meso. 3 & Meso. 4 & Meso. 5 & Meso. 6 & Meso. 7 \\
\hline$L_{\mathrm{N}}$ & 0.00 & 2.13 & 3.61 & 6.14 & 10.4 & 17.8 & 30.2 \\
$L_{\mathrm{P}}$ & 0.00 & 0.29 & 0.50 & 0.85 & 1.45 & 2.46 & 4.18 \\
$L_{\mathrm{Si}}$ & 0.00 & 4.27 & 7.25 & 12.3 & 21.0 & 35.6 & 60.6 \\
\hline
\end{tabular}


Mesozooplankton was collected from integrated samples taken separately from the mesocosms by a Ramberg sampler $(<0.1 \%$ of standing stock sampled). The sample was concentrated on a $35 \mu \mathrm{m}$ net and fixed with $1 \%$ acidic Lugol's iodine. Numbers and length measurements were obtained by microscope. Biomass of copepods was based on length-carbon biomass regressions established during the experiment (Gismervik et al. 2002). Other length-weight relationships were taken from Sabatini \& Kiørboe (1994; for cyclopoids and harpacticoids), Berggreen et al. (1988; for nauplii), Nakamura et al. (1997; for Appendicularia), Kiørboe \& Sabatini (1995; for eggs) and Kiørboe \& Sabatini (1994; for egg sacs). Small medusas were given a carbon weight of $4.4 \mu \mathrm{g} C$ based on measurements of small Sarsia sp. (length $=1.6 \mathrm{~mm}, \mathrm{n}=3$ ). Carbon weight of cladocerans was taken from Gismervik (1997).

Chemical measurements. Water for analysis of particulate C (POC) was taken from containers and filtered through a $200 \mu \mathrm{m}$ nylon screen by reverse filtration (10 l, $<200 \mu \mathrm{m}$ fraction). Approximately $6 \mathrm{l}$ of this fraction was successively size fractionated (reverse filtration) through 20 and 1 um (3 l) Nuclepore filters. Reverse filtration was carried out by gravity (pressure differential due to gravity for $<70 \mathrm{~cm}$ and a $6 \mathrm{~mm}$ diameter tube) using the siphon principle, with sample containers and suspended filter units with diameters of $150(<200 \mu \mathrm{m})$ and $50 \mathrm{~mm}(<20$ and $<1 \mu \mathrm{m})$. The water fractions (3 l) were harvested on pre-combusted $\left(450^{\circ} \mathrm{C}, 4 \mathrm{~h}\right)$ and acidwashed $\left(5 \% \mathrm{H}_{2} \mathrm{SO}_{4}\right)$ GF-F filters $(47 \mathrm{~mm})$ and frozen $\left(-18^{\circ} \mathrm{C}\right)$ before later analysis. Subsamples of $10 \mathrm{~mm}$ diameter were taken from the $47 \mathrm{~mm}$ GF-F filter for determination of POC in the fractions $(<200,<20$ and $<1 \mu \mathrm{m})$ in a CHN analyser. Dissolved organic C (DOC) in filtered (GF-F) and total organic C (TOC) in unfiltered water were analysed using catalytic high-temperature combustion and infrared detection. Detrital particulate organic carbon (DeC) was calculated as the difference between measured total POC $(<200 \mu \mathrm{m})$ and the concentration of $\mathrm{C}$ in biotic components $(<200 \mu \mathrm{m})$.

Primary production. Primary production was measured by the ${ }^{14} \mathrm{C}$-method. Radioactive bicarbonate $\left(\mathrm{H}^{14} \mathrm{CO}^{3-}, 3.6 \mu \mathrm{Ci}\right.$ bottle ${ }^{-1}$, The International Agency for ${ }^{14} \mathrm{C}$ determination) was added to a mixed sample $(0$ to $10 \mathrm{~m}$ ) from each mesocosm after transfer to 1 dark and 2 transparent bottles (63 ml, Nunc). Samples were kept in the dark until the start of incubation at $2 \mathrm{~m}$ depth in situ for $4 \mathrm{~h}$. After termination of the incubation, water samples were successively fractionated using a $20 \mu \mathrm{m}$ nylon filter, and thereafter successively 1 and $0.2 \mu \mathrm{m}$ polycarbonate filters kept in a vacuum filter unit. Water passing through the $0.2 \mu \mathrm{m}$ filter was collected for determination of dissolved organic radioactivity after acidification to $\mathrm{pH} 1$. The radioactivity of $\mathrm{HCl}$-fumed filters was measured in a scintillation counter (Pacard Tri-Carb 1900). Carbon fixation was converted to daily rates using a light factor: insolation of PAR per day divided by insolation during the incubation period. Appropriate subtraction of activity in dark bottles and the fractionations allowed estimation of primary production in the fractions 0.2 to $1 \mu \mathrm{m}, 1$ to $20 \mu \mathrm{m}$ and $>20 \mu \mathrm{m}$. Control experiments showed that $50 \%$ of the biomass of the picocyanobacteria was found in the 0.2 to $1 \mu \mathrm{m}$ fraction. Their primary production was estimated as twice the activity measured in the 0.2 to $1 \mu \mathrm{m}$ fraction.

Bacterial production. Bacterial production was measured by adding $20 \mathrm{nmol} \mathrm{l}^{-1}$ of methyl- $\left({ }^{3} \mathrm{H}\right)$-thymidine to replicate mixed samples $(10 \mathrm{ml})$ from the mesocosms. To a control sample, $1 \%$ formalin was added before addition of ${ }^{3} \mathrm{H}$-thymidine. Samples were incubated for $1 \mathrm{~h}$ at in situ temperature, and incubation was stopped by adding formaldehyde at a final concentration of $1 \%$. Samples were thereafter filtered on $0.2 \mu \mathrm{m}$ polycarbonate filters, and macromolecules were precipitated by adding $3 \times 5 \mathrm{ml}$ ice-cold TCA $(5 \%) .{ }^{3} \mathrm{H}-$ activity was measured by liquid scintillation counting and corrected for background in the pre-fixed sample. Values were converted into units of bacterial carbon production using conversion factors of $2.0 \times 10^{18}$ cells $\mathrm{mol}^{-1}$ (Bell 1993) and average $\mathrm{C}$ per cell determined by epifluorescence microscopy (see above).

Sedimentation. The sedimentation rate of $\mathrm{C}$ was estimated based on the mass balance of $\mathrm{P}$ combined with measurements of C:P in sedimented matter collected in sedimentation traps suspended at $9 \mathrm{~m}$ depth and harvested every fourth day. Sedimented P was estimated as the difference between the accumulated added $\mathrm{P}$ (as shown in Table 1) and measured total P which accumulated in the water (Grasshoff et al. 1983). This means that added $\mathrm{P}$ can either accumulate in the water or in the sediments. The corresponding sedimentation rates of $\mathrm{C}$ were then estimated based on the $\mathrm{P}$ sedimentation rates and the elemental $\mathrm{P}: \mathrm{C}$ ratio of sedimented material.

Structure of elemental flow network. The simplified planktonic food web forming a framework for the flow network construction (Fig. 1) contained 3 autotrophic groups, based on size, and 4 heterotrophic functional components, mainly based on trophic position. These groups were linked through 30 carbon flows (sedimentation not shown). As listed in Table 2, the autotrophic picoplankton (APP, $<2 \mu \mathrm{m})$ normally contain prokaryotic and eukaryotic picoplankton. The groups of autotrophic nano- (ANP, 2 to $20 \mu \mathrm{m})$ and microplankton (AMP, 20 to $200 \mu \mathrm{m}$ ) include various groups of diatoms, dinoflagellates and other optional groups. Heterotrophic bacteria (and Archaea) are the components of heterotropic picoplankton (BAC), small unpigmented nanoflagellates dominate the group of het- 
erotrophic nanoplankton (HNP), ciliates dominate heterotrophic microplankton (CIL), and copepods dominate the heterotrophic mesoplankton (COP).

The carbon flows include 4 input terms: primary production by the 3 autotrophic groups and BAC uptake of DOC; 17 output terms express release of DOC and respiratory $\mathrm{CO}_{2}$ (dissolved inorganic carbon, DIC) from all components and release of DeC from zooplankton. DOC and DeC release originate from exudation, excretion, egestion, defecation and mortality. Zooplankton predation accounts for 8 flows, and the final flow, sedimentation of $\mathrm{DeC}$, closes the pelagic mass balance. A higher number of flows could have been considered, but this would have deteriorated the robustness of the results.

Flow rate estimation by inverse modelling. A mass balance equation is associated with each of the functional components of the flow network, relating net rate of change to sums of flows in and out of this compartment. The resulting equation system will always be under-determined, with more unknowns than equations. Additional equations will result from any flows that are measured directly, here primary and bacterial production and sedimentation. Solutions had

Table 2. Review of the dominant organisms assigned to the different functional food web components

\begin{tabular}{|c|c|}
\hline Component & Dominant taxonomic groups/species \\
\hline APP, autotrophic picoplankton & Prokaryotic picocyanobacteria, traces of picoeukaryotes $(<2 \mu \mathrm{m})$ \\
\hline ANP, autotrophic nanoplankton & $\begin{array}{l}\text { Diatoms (Rhizosolenia fragilissima, unidentified centric), Rhodomonas sp. and uniden- } \\
\text { tified pigmented flagellates, small thecate dinoflagellates (traces) (widths: } 2 \text { to } 20 \mu \mathrm{m} \text { ) }\end{array}$ \\
\hline AMP, autotrophic microplankton & $\begin{array}{l}\text { Diatom colonies (Skeletonema costatum), large dinoflagellates (Ceratium spp., } \\
\text { Dinophysis spp., Protoperidinium spp.), autotrophic ciliates (widths: }>20 \mu \mathrm{m} \text { ) }\end{array}$ \\
\hline BAC, heterotrophic picoplankton & Heterotrophic bacteria, including Archaea (diameter: $<1 \mu \mathrm{m}$ ) \\
\hline HNP, heterotrophic nanoplankton & $\begin{array}{l}\text { Heterotrophic nanoflagellates ( } 2 \text { to } 8 \mu \mathrm{m}, 62 \%) \text {, Oikopleura dioica }(14 \%) \text {, Craspedo- } \\
\text { phyceae }(13 \%) \text {, bacterivore ciliates (scuticociliates, small oligotrichs, } 11 \% \text {; } \\
\text { Gismervik et al. 2002) }\end{array}$ \\
\hline CIL, heterotrophic microplankton & $\begin{array}{l}\text { Herbivore ciliates (strombidids, strobilids, } 20 \text { to } 50 \mu m_{i} \text { Gismervik et al. 2002), } \\
\text { Protoperidinium spp. (traces) }\end{array}$ \\
\hline COP, heterotrophic mesoplankton & $\begin{array}{l}\text { Calanoid copepods (Acartia spp., Centrophages spp., Temora longicornis, } \\
\text { Pseudocalanus sp., Paracalanus parvus), cyclopoid copepods (Oithona sp.) } \\
\text { (Gismervik et al. 2002) }\end{array}$ \\
\hline
\end{tabular}

Table 3. Rules used to constrain food web flows estimated by inverse modelling. GPP: gross primary production or total dissolved inorganic carbon (DIC) uptake in autotrophs ( $\left.\mu \mathrm{g} \mathrm{C} \mathrm{l}^{-1} \mathrm{~d}^{-1}\right)$; \% GE: growth efficiency of heterotrophs (\% growth of ingestion); DOC: dissolved organic carbon; DeC: detrital organic C. For component abbreviations and descriptions see Table 2

\begin{tabular}{|c|c|c|c|}
\hline Flow & Component & Constraint/rule & Source \\
\hline All flows & All & $0<$ Flow $<$ Maximum flow & \\
\hline DOC release (exudation, lysis) & APP, ANP, AMP & $(0.05-0.5) \times \mathrm{GPP}$ & Vézina (1989) \\
\hline Specific DIC release (respiration) & $\begin{array}{c}\mathrm{APP}, \mathrm{ANP}, \mathrm{AMP} \\
\text { BAC } \\
\mathrm{HNP}, \mathrm{CIL} \\
\text { COP }\end{array}$ & $\begin{array}{l}0.05 \mathrm{~d}^{-1} \\
0.05 \mathrm{~d}^{-1} \\
0.20 \mathrm{~d}^{-1} \\
0.07 \mathrm{~d}^{-1}\end{array}$ & Vézina (1989) \\
\hline Maximum clearance rates & $\begin{array}{c}\text { HNP } \\
\text { CIL, COP }\end{array}$ & $\begin{array}{l}0.021 \mu \mathrm{g} \mathrm{C}^{-1} \mathrm{~d}^{-1} \\
0.02 \mathrm{l} \mu \mathrm{g} \mathrm{C}^{-1} \mathrm{~d}^{-1}\end{array}$ & $\begin{array}{l}\text { Modified from Fenchel (1982) } \\
\text { Gismervik et al. (1996) }\end{array}$ \\
\hline Maximum specific ingestion rate $\left(I_{c}\right)$ & $\begin{array}{c}\text { HNP } \\
\text { CIL } \\
\text { COP }\end{array}$ & $\begin{array}{l}8 \mathrm{~d}^{-1} \\
4 \mathrm{~d}^{-1} \\
2 \mathrm{~d}^{-1}\end{array}$ & \\
\hline Clearance rate, CR (selectivity) & $\mathrm{COP}$ & $\begin{array}{c}\text { CR for CIL }>\text { CR for AMP }>\text { CR for } \\
\text { ANP }>\text { CR for HNP }\end{array}$ & \\
\hline Growth efficiency (\%GE) & $\begin{array}{l}\mathrm{HNP}, \mathrm{CIL}, \mathrm{COP} \\
\mathrm{COP}\end{array}$ & $\begin{array}{c}10-60 \\
<40\end{array}$ & Vézina (1989) \\
\hline Net rate of change & $\mathrm{DeC}$ & 0 for all mesocosms & \\
\hline
\end{tabular}


to satisfy a number of a priori inequality constraints that can be derived from general physical and physiological limitations (Table 3). The resulting systems of equations and inequality constraints were solved for the unknown flows by the Vézina \& Platt (1988) algorithm, yielding constrained minimum-norm leastsquare solutions. These will henceforth be called the inverse solutions, and their vector elements will be called the reconstructed flows.

The key element in the first part of the Vézina-Platt algorithm is a matrix factorisation called singular value decomposition (SVD), one of the numerically most stable methods for solving a least-squares problem. The second part applies a least-distance algorithm to a subset of the SVD solution (corresponding to the most significant singular values), such that the inequality constraints become satisfied. One remaining problem is to choose the number of singular values. While it would be natural to use the rank of the equation system if our measurements were error free, this is seldom possible in practical situations. Vézina \& Platt (1988) recommend graphing the solution and residual norms for different numbers of singular values, and choosing the value closest to where the curves intersect. Our experience is that the inversion algorithm may often be unable to find any solution at all when the number of singular values is close to the rank of the system. Unfortunately, this can only be detected when substituting the solution back into the original constraints (which will then be violated). We have thus included as a default in our implementation a linear search for the highest rank solution that actually satisfies the constraints. We used Matlab software (The MathWorks) for our implementation of the Vézina-Platt algorithm.

\section{RESULTS}

The input rate of dissolved inorganic nitrogen and phosphorus (DIN and DIP, respectively) affected DIN and DIP concentrations temporarily during the first 7 to $9 \mathrm{~d}$ in mesocosms with high amounts of nutrients added (Fig. 2A,B). The mean concentration was significantly and positively related to the nitrogen input (or loading) rate $\left(L_{\mathrm{N}}, \mathrm{p}<0.001\right.$ for both), which is proportional to the phosporus input rate $L_{\mathrm{P}}$ (Table 1$)$. Phytoplankton production (Fig. 2C, sum for all groups) responded quite fast and peaked on Day 9 and again on Day 17. The accu-
Fig. 2. Input data used for flow network reconstruction: inorganic nutrients, measured production and biomasses as functions of $\mathrm{N}$ input rate $\left(L_{\mathrm{N}}\right)$ and time ( $\mathrm{n}=70$ for individual graphs). (A) Dissolved inorganic N (DIN); (B) dissolved inorganic P (DIP); (C) gross primary production (GPP) of autotrophs (sum of all groups); (D) gross bacterial production (GBP) of heterotrophic picoplankton (i.e. bacteria, BAC); (E) autotrophic biomass (sum of all groups); and (F) bacterial biomass (BAC) 
HNP biomass $\left(\mu \mathrm{g} \mathrm{C}^{-1}\right)$
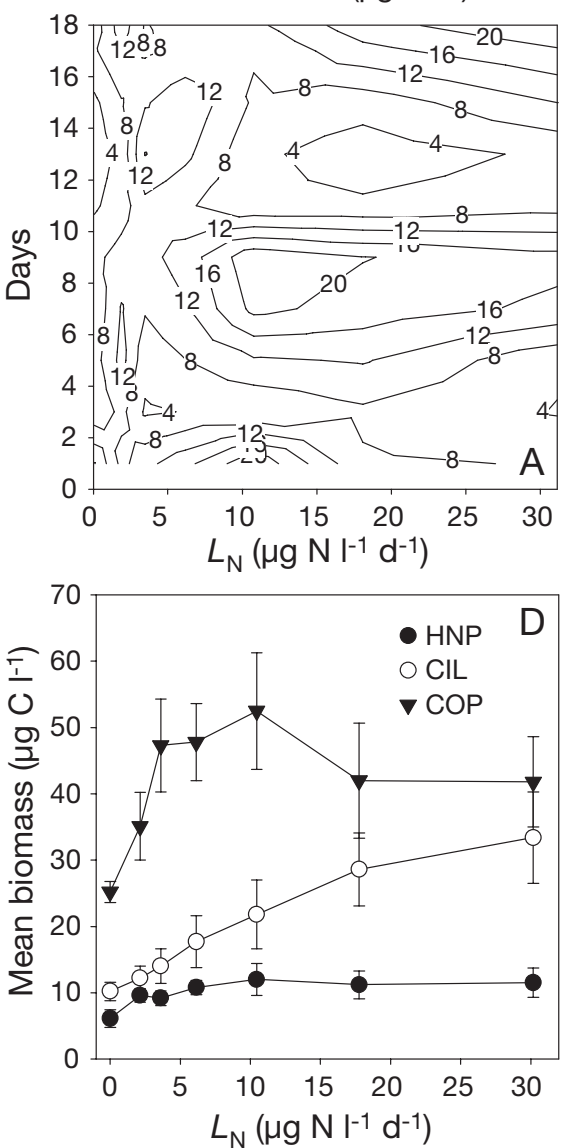

CIL biomass $\left(\mu \mathrm{g} \mathrm{C} \mathrm{I}^{-1}\right)$
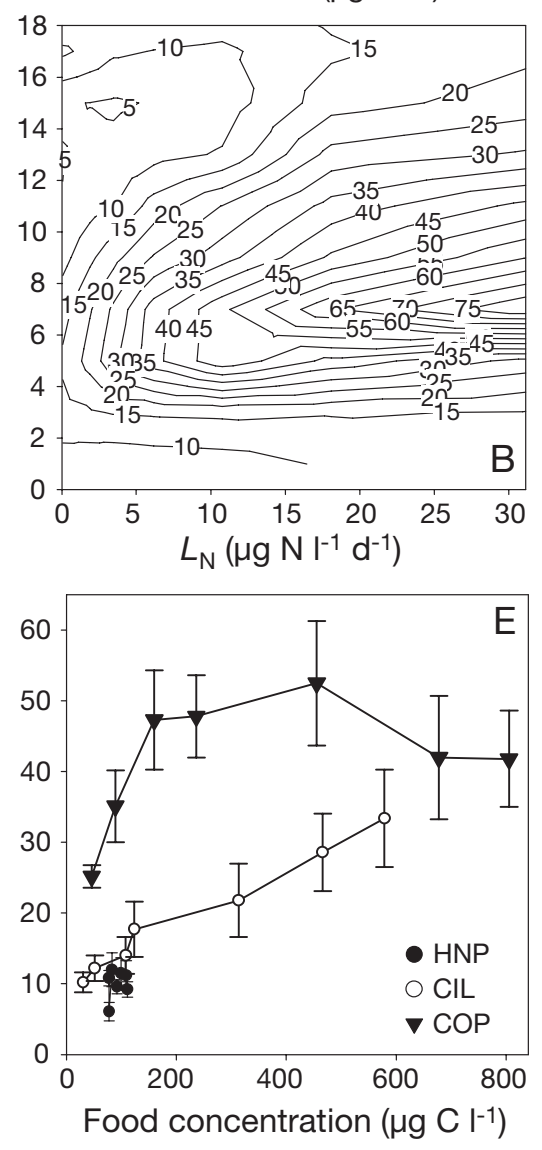

COP biomass $\left(\mu \mathrm{g} \mathrm{Cl}^{-1}\right)$
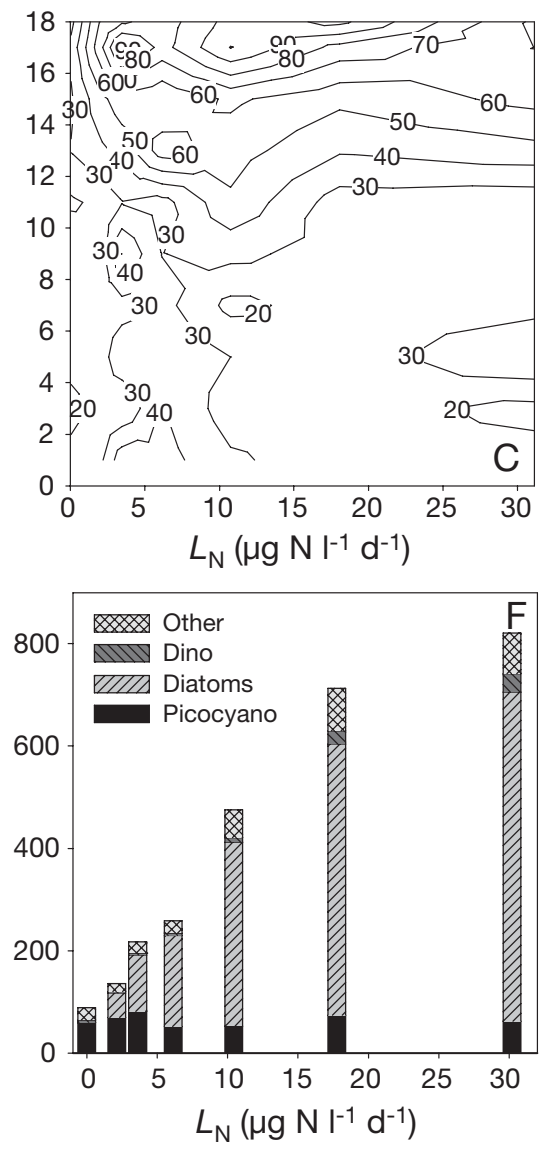

Fig. 3. (A-D) Input data of zooplankton biomass as functions of $\mathrm{N}$ input rate $L_{\mathrm{N}}$ and time ( $\mathrm{n}=70$ for individual graphs) used for flow network reconstruction and (E,F) food characteristics of zooplankton. (A) HNP biomass; (B) CIL biomass; (C) COP biomass; (D) mean zooplankton biomass as a function of $L_{\mathrm{N}}( \pm 1 \mathrm{SE}) ;(\mathrm{E})$ mean zooplankton biomass as a function of their specific food concentration ( $\pm 1 \mathrm{SE})$; and $(\mathrm{F})$ phytoplankton composition (abbreviations, see Table 2)

mulation of total phytoplankton biomass (Fig. 2E) responded slightly slower, peaking between Days 13 and 15. Both the production and biomass were significantly and positively related to the $L_{\mathrm{N}}$ ( $\mathrm{p}<0.001$ for both). BAC production and biomass increased significantly with nutrient input $(\mathrm{p}<0.001$ and $\mathrm{p}<0.01$, respectively), and both peaked around Days 9 to 13 (Fig. 2D), which was slightly after the primary production.

The input biomass data for the zooplankton groups (Fig. 3A-C) revealed different response patterns (Fig. 3D, mean biomasses). The HNP was diverse, and the group responded very moderately, although significantly ( $\mathrm{p}<0.05$ ), to nutrient addition (Fig. 3A,D). Unpigmented nanoflagellates in the size range of 2 to $8 \mu \mathrm{m}$ dominated the HNP, constituting on average $62 \%$ of the HNP biomass (range 41 to $73 \%$ for the mesocosms). The appendicularians Oikopleura sp. were assigned to HNP because their feeding on picoplankton was assumed to be more important for the carbon flows than their role as prey (i.e. size). Other groups included were Craspedophyceae sp. (13\%) and bacterivore ciliates $(11 \%)$. Herbivore ciliates were clearly dominant among CIL (Fig. 3B,D), and the group responded fast and significantly to nutrient addition ( $\mathrm{p}<0.001)$, peaking between Days 5 and 7 . It took $11 \mathrm{~d}$ before copepods, which dominated COP, responded to the treatment (Fig. 3C,D). Acartia spp. became dominant at the highest nutrient input, whereas both Acartia spp. and Centropages spp. remained dominant in the lower range (Gismervik et al. 2002). The response pattern of COP was not linearly related to $L_{\mathrm{N}}$ (Fig. 3D). The mean biomass increased in the lower range of nutrient input rates and was reduced at high input (Fig. 3C, details in Gismervik et al. 2002). Carnivore hydromedusas (Sarsia sp., Podocoryne carnea) were found in densities of 0.2

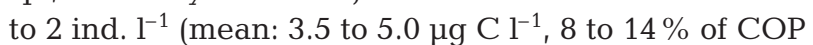
biomass), with the highest concentrations at the end of the experiment. The group was not assigned to 
COP because members feed on copepods (Stibor \& Tokle 2003).

The response in COP biomass levelled off and became reduced above a food concentration of $200 \mu \mathrm{g}$ $\mathrm{C}^{-1}$, whereas CIL biomass appeared to increase in a linear mode over the whole range of food concentrations (Fig. 3E). The concentration of food for HNP (APP and BAC, Fig. 1) responded very little to enhanced nutrient input rates (Figs. 2F \& 3F), although bacteria had a more marked response than APP. This is in agreement with the low response of HNP biomass (Fig. 3E). The main component of the food for CIL and COP were diatoms, which responded most strongly to nutrient enrichment (Fig. 3F). Responses in other autotrophic organisms were moderate.

The input data for the flow network reconstruction by inverse modelling involved the carbon mass of 8 components (560 measured values, most based on many

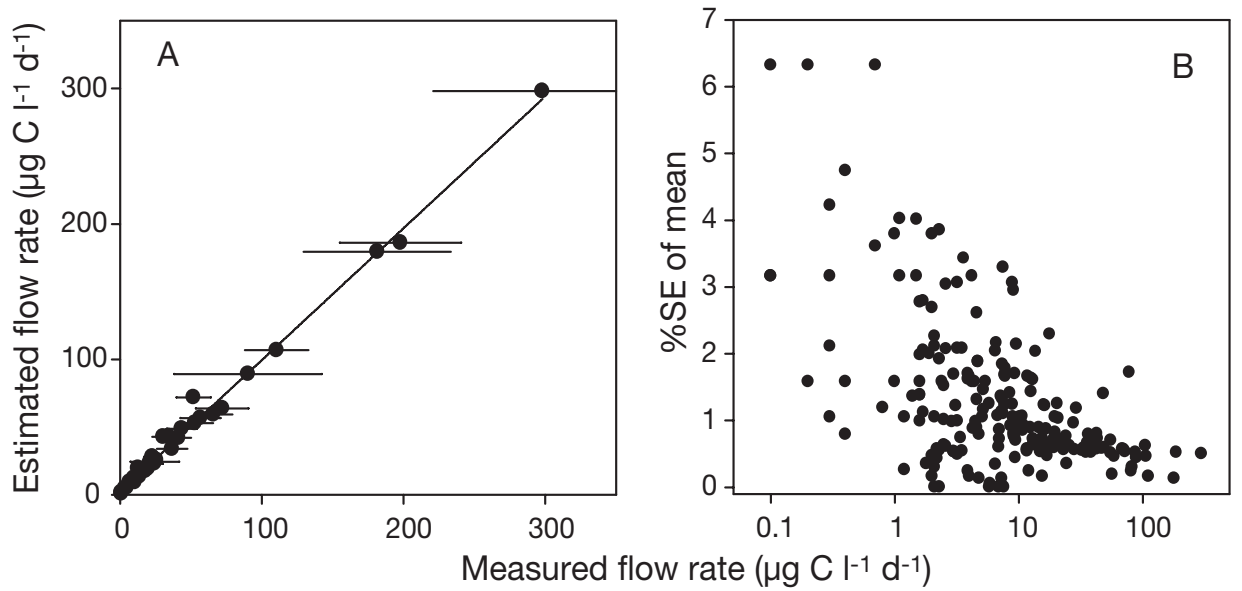

Fig. 4. Characteristics of estimated carbon flow rates. (A) Estimated flow rate as a function of the corresponding measured flow rate $(\mathrm{n}=35)$. Measured flows were primary production for APP, ANP and AMP, production of the bacteria (BAC), and sedimentation of DeC. Error bars \pm 1 SE (hidden by symbol for estimated flows along $y$-axis). (B) Coefficient of variation of flow rate estimates (mean of Monte Carlo simulations) as a function of the measured flow rate (abbreviations, see Table 2)
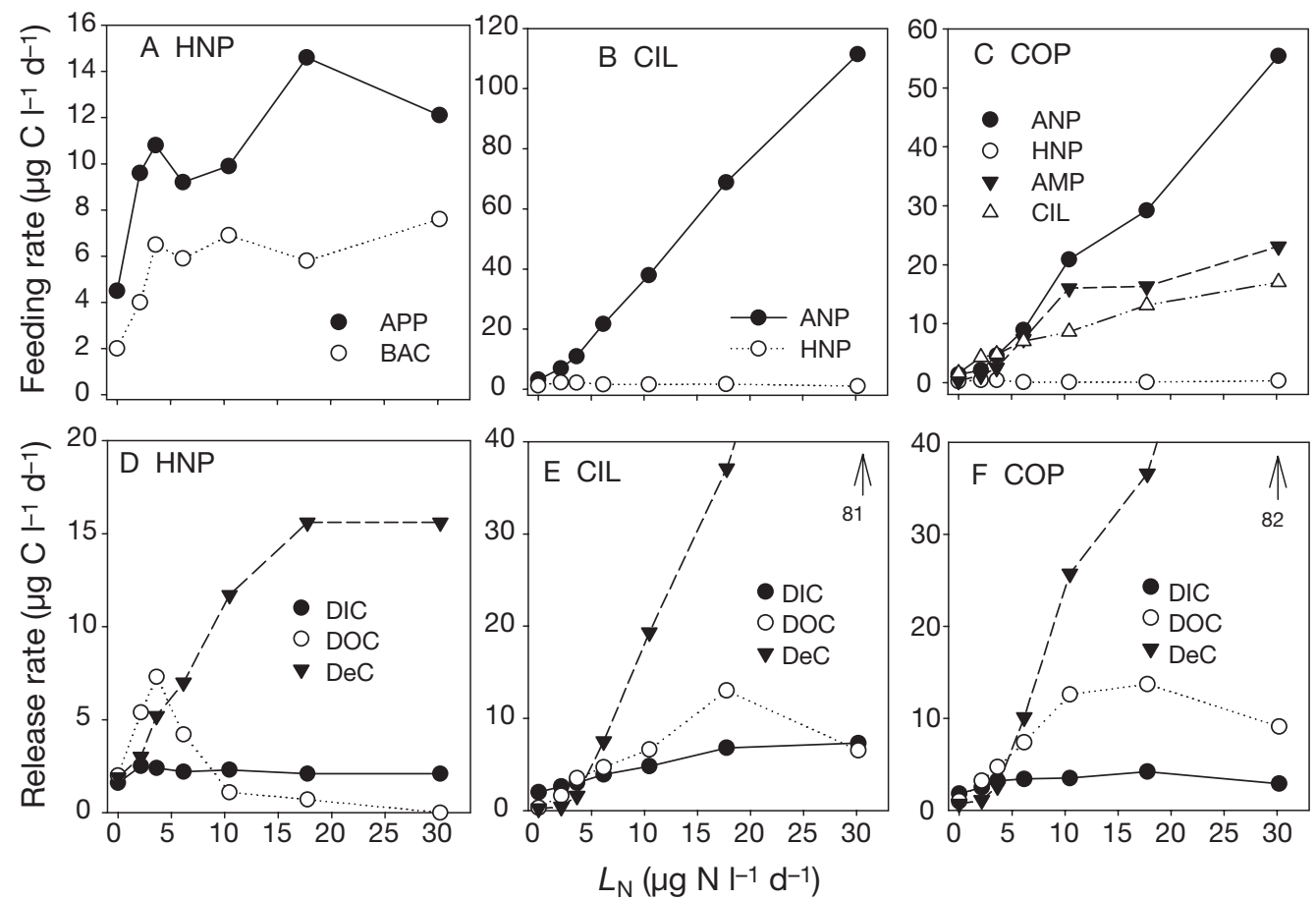

Fig. 5. (A to C) Estimated carbon feeding rates $\left(i_{c}\right)$ of the different food sources and (D to F) release flow rates $\left(e_{c}\right)$ of DIC, DOC and DeC for the 3 zooplankton groups as a function of input rate $\left(L_{N}\right)$. Numbers with arrows $(\mathrm{E}, \mathrm{F})$ : maximum offscale values. Note different scales on $y$-axes. Abbreviations, see Tables $2 \& 3$ 
Table 4. Regression coefficients for carbon consumption rates (autotrophic carbon and total carbon) and total carbon release rates of the heterotrophic groups versus gross primary production (GPP). TZOO: total zooplankton; other abbreviations, see Table 2

\begin{tabular}{|c|c|c|c|c|}
\hline $\begin{array}{l}\text { Relationship } \\
\text { Group }\end{array}$ & $\begin{array}{l}\text { Slope } \\
\pm 1 \mathrm{SE}\end{array}$ & $\begin{array}{l}\text { Intercept } \pm 1 \mathrm{SE} \\
\quad\left(\mu \mathrm{C} \mathrm{C}^{-1} \mathrm{~d}^{-1}\right)\end{array}$ & $\mathrm{r}^{2}$ & $\mathrm{p}$ \\
\hline \multicolumn{5}{|c|}{ Autotrophic carbon consumption rate versus GPP } \\
\hline HNP & $0.015 \pm 0.007$ & $7.77 \pm 1.4$ & 0.484 & 0.08 \\
\hline CIL & $0.280 \pm 0.009$ & $-5.79 \pm 1.72$ & 0.995 & $<0.0001$ \\
\hline COP & $0.198 \pm 0.011$ & $-3.38 \pm 2.26$ & 0.992 & $<0.0001$ \\
\hline TZOO & $0.493 \pm 0.007$ & $-1.39 \pm 1.45$ & 0.999 & $<0.0001$ \\
\hline \multicolumn{5}{|c|}{ Total carbon consumption rate versus GPP } \\
\hline HNP & $0.025 \pm 0.010$ & $11.9 \pm 2.0$ & 0.743 & 0.055 \\
\hline CIL & $0.278 \pm 0.008$ & $-3.85 \pm 1.56$ & 0.998 & $<0.0001$ \\
\hline $\mathrm{COP}$ & $0.235 \pm 0.010$ & $-0.823 \pm 2.06$ & 0.995 & $<0.0001$ \\
\hline TZOO & $0.538 \pm 0.006$ & $7.18 \pm 1.28$ & 0.999 & $<0.0001$ \\
\hline \multicolumn{5}{|c|}{ Total carbon release rate versus GPP } \\
\hline HNP & $0.024 \pm 0.009$ & $9.98 \pm 1.77$ & 0.778 & $<0.05$ \\
\hline CIL & $0.240 \pm 0.009$ & $-6.34 \pm 1.82$ & 0.996 & $<0.0001$ \\
\hline COP & $0.231 \pm 0.010$ & $-2.36 \pm 1.99$ & 0.996 & $<0.0001$ \\
\hline TZOO & $0.495 \pm 0.007$ & $1.29 \pm 1.42$ & 0.999 & $<0.0001$ \\
\hline
\end{tabular}

low nutrient input (Fig. 5A-C). The relatively continuous pattern of feeding rates versus $L_{\mathrm{N}}$ was not obvious $a$ priori, because all flows were independently estimated for each mesocosm unit. APP were the most important food for HNP, but BAC was important as well. ANP were by far the most important food source for COP and CIL, especially for CIL. In addition, COP fed on AMP and CIL in comparable amounts. The consumption of HNP by CIL and COP was almost negligible in nutrient-enriched communities. The feeding rate for COP in Mesocosm 7 is most likely overestimated (see below, this section).

The consumption rates of autotrophic and total carbon were both positively related to gross primary production (GPP) for all heterotrophic groups and total zooplankton (TZOO) measurements) and 5 measured flows (315 values) organised in dose-dayparameter value matrixes. The input to sedimentation was given as mean flows for the mesocosms. This included in total 875 input values for the 13 variables. We obtained full rank flow solutions for all mesocosms. Estimated flows were on average slightly lower than the corresponding measured input flows (Fig. 4A, slope 0.972 \pm 0.014 , $\left.\mathrm{p}<0.0001, \mathrm{r}^{2}=0.993\right)$. The confidence limits of mean measured flows (Fig. 4A) and biomasses (e.g. Fig. 3D, 6 to $42 \%$ ) were mainly a result of the variability measured from day to day throughout the experiment. The uncertainty of the mean flow estimates, derived from 3000 Monte Carlo simulations, was from 0.1 to $6 \%$, with highest relative variability for small flows (Fig. 4B). The narrow confidence limits of the flows are not shown in Figs. 5 to 7. The variability is better illustrated through the relationship between the independently generated flows from the 7 individual mesocosms along the gradient of increasing nutrient addition.

Carbon feeding flows of CIL and COP increased with increasing nutrient input rate, whereas feeding of HNP showed saturation at relatively
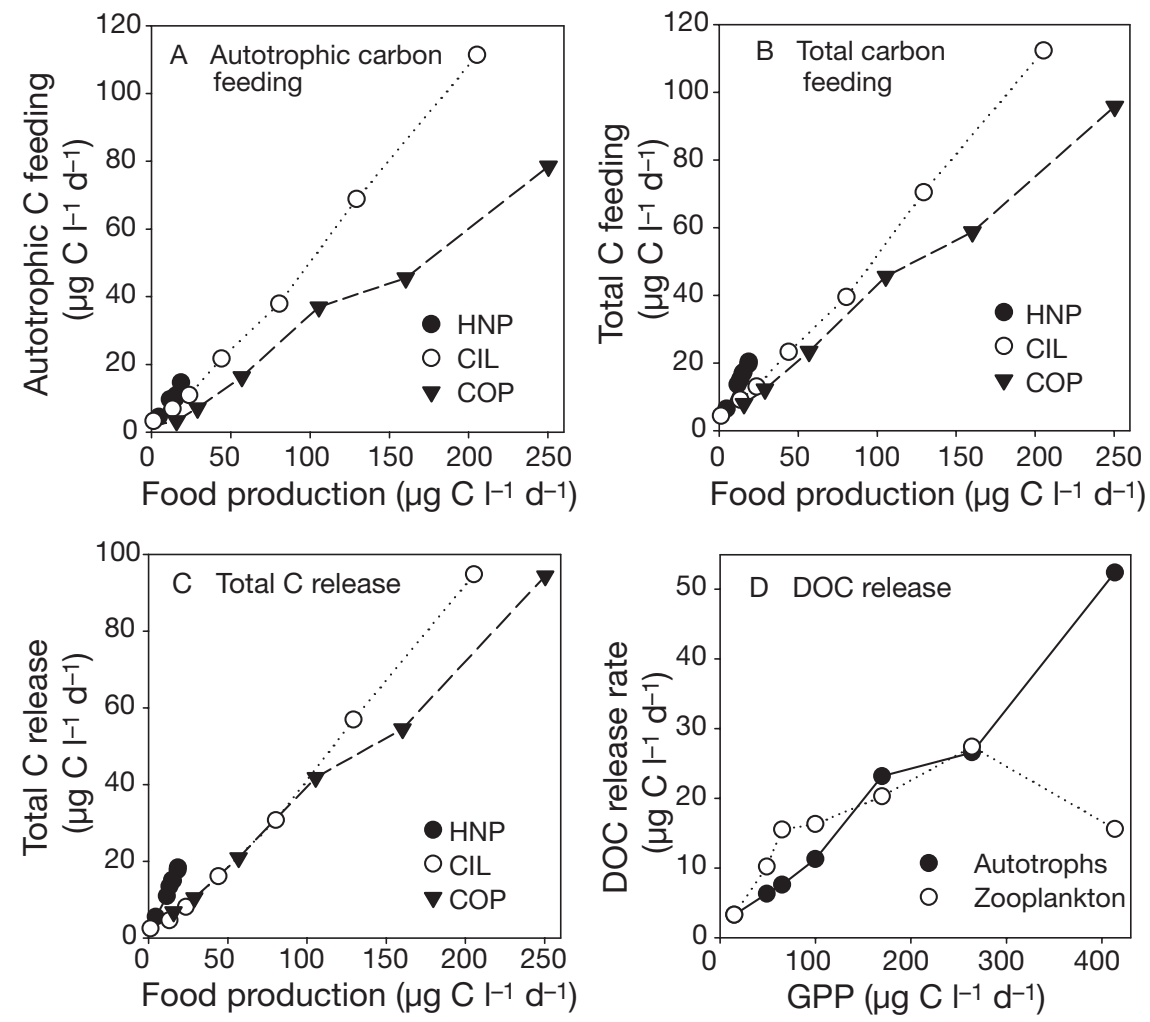

Fig. 6. Group-specific carbon consumption and release rates of the zooplankton groups: $(\mathrm{A})$ autotrophic feeding rate and $(\mathrm{B})$ total feeding rate $\left(i_{\mathrm{C}}\right)$ for the 3 zooplankton groups as a function of their respective food production rate; $(C)$ total carbon release rate from the 3 zooplankton groups $\left(e_{\mathrm{tc}}\right)$ as a function of their respective food production rate; and (D) rate of DOC release from heterotrophs and autotrophs (see Fig. 1) as a function of gross primary production (GPP). Abbreviations, see Tables $2 \& 3$ ) 
(Table 4), although not statistically significant for HNP ( $p>0.05$ ). The feeding responses of all zooplankton groups on autotrophic carbon (Fig. 6A) and total carbon (Fig. 6B) were significantly and positively related to the respective rate of food production $(p<0.001$ for all). The fraction of autotrophic food carbon remained constant for HNP (65\%, range: 59 to $72 \%$ ), whereas it increased significantly ( $\mathrm{p}<0.05$ ) with increasing nutrient input for CIL (range: 73 to $99 \%$, mean: $88 \%$ ) and COP (range: 41 to $82 \%$, mean: $65 \%$ ). The overall mean fraction of autotrophic food of total consumption was $76 \%$.

All zooplankton groups showed an increase in respiration (DIC release) with increasing nutrient input (Fig. 5D-F). The pattern of increase was comparable to that of the heterotrophic biomass (Fig. 3D). HNP exhibited an increased release of both DOC and DeC for low nutrient inputs, but DOC release was reduced at high input. DOC and DeC may originate from sloppy feeding, excretion, defecation and mortality. CIL and COP showed a moderate increase in DOC release, with an optimum at intermediate nutrient input rates and a strong and steady increase in DeC release above nutrient input rates of 3.6 to $6.2 \mu \mathrm{g} \mathrm{N}^{-1} \mathrm{~d}^{-1}$. The pronounced release of DeC definitely contained an element of enhanced zooplankton mortality in all communities, but the value is most likely overestimated in Mesocosm 7 (see 'Discussion').

All zooplankton groups, including TZOO, showed total carbon release rates that increased significantly with increasing GPP ( $p<0.05$, Table 4) and the food production of the group (Fig. 6C, p $<0.0001$ for all). The combined losses of DIC, DOC and DeC for TZOO constituted close to $50 \%$ of the GPP in strongly enriched mesocosms, and combined losses estimated by extrapolation to zero GPP were not significantly different from zero $(p=0.41)$. DOC constituted a major fraction of the total $\mathrm{C}$ release from the zooplankton, and zooplankton and phytoplankton supplied DOC in comparable rates in most mesocosms (Fig. 6D).

The following treatment of carbon flows was based on the simple mass balance equation for their main anabolic processes and losses:

$$
i_{\mathrm{C}}=g_{\mathrm{c}}+r+e_{\mathrm{c}}=a_{\mathrm{c}}+e_{\mathrm{c}}
$$

where $i_{\mathrm{C}}$ is ingestion, $g_{\mathrm{c}}$ is retention of carbon in biomass (growth and reproduction), $r$ is respiration of $\mathrm{CO}_{2}$ and $e_{\mathrm{c}}$ is the sum of mortality and total egested organic carbon through sloppy feeding, excretion and defecation $\left(e_{\mathrm{DOC}}+e_{\mathrm{DeC}}\right)$. All are expressed in terms of micrograms of $\mathrm{C}$ per litre per day. Assimilation $\left(a_{\mathrm{C}}\right)$ is the sum of growth and respiration $\left(g_{\mathrm{c}}+r\right)$.

The growth and assimilation flows generated were sound throughout, compared to the ingestion rates (Table 5). Assimilation and growth were relatively sta- ble in HNP and increased steadily with GPP in CIL and COP, but decreased for COP in Mesocosm 7. The validity of these metabolic flows is best illustrated through the estimates of assimilation efficiency (AE, $a_{\mathrm{C}}$ $\left.i_{\mathrm{C}}{ }^{-1}\right)$ and $\mathrm{GE}\left(g_{\mathrm{C}} i_{\mathrm{C}}{ }^{-1}\right)$ of the zooplankton groups (Fig. 7). For all zooplankton groups, AE was gradually decreased as the nutrient input rate and GPP increased. At low GPP, the highest AE was found for CIL and the lowest for HNP, with COP showing intermediate values (Fig. 7A). The same pattern of variation was apparent for the GE (Fig. 7B), but GE showed reduced values for all groups at the lowest GPP (no nutrient addition). Both $\mathrm{AE}$ and GE deviated from a hyperbola-like pattern for COP (and TZOO) at the highest GPP (Mesocosm 7). The same trend may be apparent also for CIL in Mesocosm 7 (discussed below).

The results from Mesocosm 1 to 4 (Table 1) may represent the normal range of variability in nutrient input

Table 5. Gross primary production (GPP, $\mu \mathrm{g} \mathrm{C}^{-1} \mathrm{~d}^{-1}$ ), mean biomass ( $\mu \mathrm{g} \mathrm{Cl}^{-1}$ ) and estimated metabolic flows of zooplankton groups ( $\mu \mathrm{C} \mathrm{C}^{-1} \mathrm{~d}^{-1}$ ). $g_{\mathrm{c}}$ : carbon for growth and reproduction; $a_{\mathrm{c}}$ : assimilated carbon; $r$ : respiration; $e_{\mathrm{c}}+m_{\mathrm{c}}$ : total losses of organic carbon and mortality; $i_{\mathrm{c}}$ : ingested carbon; TZOO: total zooplankton; other abbreviations, see Table 2

\begin{tabular}{|lcrrrrr|}
\hline GPP & Mean biomass & $g_{\mathrm{c}}$ & $a_{\mathrm{C}}$ & $r$ & $e_{\mathrm{c}}+m_{\mathrm{c}}$ & $i_{\mathrm{C}}$ \\
\hline HNP & & & & & & \\
15.0 & 6.12 & 1.0 & 2.6 & 1.6 & 3.9 & 6.5 \\
49.1 & 9.63 & 2.7 & 5.2 & 2.5 & 8.4 & 13.6 \\
65.2 & 9.24 & 2.4 & 4.8 & 2.4 & 12.5 & 17.3 \\
99.9 & 10.8 & 1.7 & 3.9 & 2.2 & 11.2 & 15.1 \\
170 & 12.0 & 1.7 & 4.0 & 2.3 & 12.8 & 16.8 \\
264 & 11.2 & 2.0 & 4.1 & 2.1 & 16.3 & 20.4 \\
414 & 11.5 & 2.0 & 4.1 & 2.1 & 15.6 & 19.7 \\
CIL & & & & & & \\
15.0 & 10.2 & 1.9 & 3.9 & 2.0 & 0.5 & 4.4 \\
49.1 & 12.2 & 4.6 & 7.2 & 2.6 & 2.0 & 9.2 \\
65.2 & 14.0 & 5.0 & 8.0 & 3.0 & 5.1 & 13.1 \\
99.9 & 17.7 & 7.2 & 11.1 & 3.9 & 12.2 & 23.3 \\
170 & 21.8 & 8.8 & 13.6 & 4.8 & 25.9 & 39.5 \\
264 & 28.6 & 13.6 & 20.4 & 6.8 & 50.1 & 70.5 \\
414 & 33.4 & 17.6 & 24.9 & 7.3 & 87.5 & 112 \\
COP & & & & & & \\
15.0 & 25.2 & 0.0 & 1.8 & 1.8 & 1.7 & 3.5 \\
49.1 & 35.1 & 1.2 & 3.7 & 2.5 & 4.3 & 8.0 \\
65.2 & 47.3 & 1.8 & 5.0 & 3.2 & 7.3 & 12.3 \\
99.9 & 47.8 & 2.5 & 5.9 & 3.4 & 17.5 & 23.4 \\
170 & 52.5 & 3.8 & 7.3 & 3.5 & 38.3 & 45.6 \\
264 & 42.0 & 4.2 & 8.4 & 4.2 & 50.3 & 58.7 \\
414 & 41.8 & 1.4 & 4.3 & 2.9 & 91.5 & 95.8 \\
TZOO & & & & & & \\
15.0 & 41.5 & 2.9 & 8.30 & 5.4 & 6.1 & 14.4 \\
49.1 & 56.9 & 8.5 & 16.1 & 7.6 & 14.7 & 30.8 \\
65.2 & 70.6 & 9.2 & 17.8 & 8.6 & 24.9 & 42.7 \\
99.9 & 76.3 & 11.4 & 20.9 & 9.5 & 40.9 & 61.8 \\
170 & 86.3 & 14.3 & 24.9 & 10.6 & 77.0 & 102 \\
264 & 81.8 & 19.8 & 32.9 & 13.1 & 117 & 150 \\
414 & 86.7 & 21.0 & 33.3 & 12.3 & 195 & 228 \\
& & & & & & \\
\hline
\end{tabular}




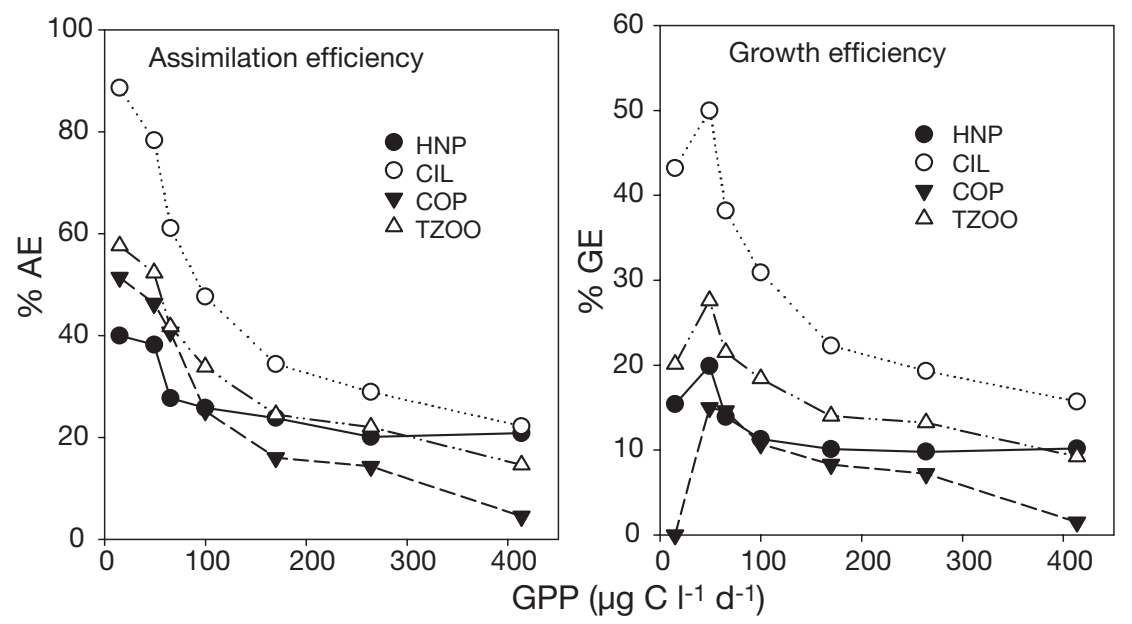

Fig. 7. Metabolic efficiencies of the zooplankton groups: (A) assimilation efficiency of $\mathrm{C}(\% \mathrm{AE})$ as a function of gross primary production (GPP) and (B) growth efficiency of C (\% GE) as a function of GPP. TZOO: total zooplankton; other abbreviations, see Table 2

rate at the experimental site, and the mean carbon flows for these units are assumed to be representative for the undisturbed normal situation during the summer season. Our results confirmed that an input of 2.1 to $3.6 \mu \mathrm{g} \mathrm{N} \mathrm{l}^{-1} \mathrm{~d}^{-1}$ to the mesocosms (range for Mesocosms 2 and 3) gave mean chlorophyll levels of 2 to $3 \mu \mathrm{g} \mathrm{chl} \mathrm{a} \mathrm{l}^{-1}$, which is the normal range of variation found in the lagoon system during June to September (authors' unpubl. results). The average flows for Mesocosms 5 to 7 can represent a strongly nutrient enriched situation.
The normal situation was characterised by approximately equal contributions of all 3 zooplankton groups to carbon feeding and release (Figs. 8A \& 9A). Increased nutrient input resulted in a pronounced increase in feeding and $\mathrm{DeC}$ release by $\mathrm{CIL}$ and $\mathrm{COP}$, whereas their biomasses and respiratory flows increased only slightly. The release of DOC exhibited a moderate increase with increasing nutrient input in CIL and COP, and both these groups exhibited increased carbon retention through assimilation, growth and reproduction (Fig. 9). CIL was the strongest responding group. The overall pattern will not change essentially if carbon ingestion and $\mathrm{DeC}$ release are overestimated in Mesocosm 7 for COP, and perhaps also for CIL, as suggested above. Carbon ingestion for $\mathrm{COP}$ at high nutrient input was reduced from 67 to $52 \mathrm{\mu g} \mathrm{C} \mathrm{l}^{-1} \mathrm{~d}^{-1}$ with Mesocosm 7 excluded. HNP, for which food availability was little affected by enhanced nutrient input, responded by slightly higher feeding and $\mathrm{DeC}$ release rates, no response in carbon assimilation and retention $\left(a_{\mathrm{c}}\right.$ and $g_{\mathrm{C}}$ respectively), and a small increase in biomass.

The specific growth and respiration rates of CIL and COP were slightly higher for high than for normal nutrient input, but the increase was not significant $(\mathrm{p}>$

Table 6. Mean values for selected specific flows, assimilation efficiency ( $\%$ AE) and growth efficiency ( $\%$ GE) estimated for lower (mean for Mesocosms 1 to 4, $\mathrm{n}=4$ ) and higher (mean for Mesocosms 5 to $7, \mathrm{n}=3$ ) range of nutrient input rate. p: probability for significant differences in value estimated for low- and high-nutrient input rates ( $t$-test). $a_{\mathrm{C}}, i_{\mathrm{C}}$ and $g_{\mathrm{c}}$ : assimilation, ingestion and retention of carbon, respectively. For other abbreviations, see Table 2

\begin{tabular}{|c|c|c|c|c|}
\hline Variable & Group & $\mathrm{p}$ & $\begin{array}{l}\text { Range low nutrients } \\
\left(0 \text { to } 6.2 \mu \mathrm{g} \mathrm{N} \mathrm{l}^{-1} \mathrm{~d}^{-1}\right)\end{array}$ & $\begin{array}{l}\text { Range high nutrients } \\
\left(10.5 \text { to } 30.2 \mathrm{~g} \mathrm{~N}^{-1} \mathrm{~d}^{-1}\right)\end{array}$ \\
\hline Specific growth rate $\left(\mathrm{d}^{-1}\right)$ & $\begin{array}{l}\text { HNP } \\
\text { CIL } \\
\text { COP } \\
\text { TZOO }\end{array}$ & $\begin{array}{r}0.26 \\
0.09 \\
0.13 \\
<0.05\end{array}$ & $\begin{array}{r}0.22 \pm 0.03 \\
0.33 \pm 0.05 \\
0.031 \pm 0.011 \\
0.13 \pm 0.02\end{array}$ & $\begin{array}{r}0.17 \pm 0.01 \\
0.47 \pm 0.04 \\
0.069 \pm 0.020 \\
0.22 \pm 0.03\end{array}$ \\
\hline Specific respiration rate $\left(\mathrm{d}^{-1}\right)$ & $\begin{array}{l}\text { HNP } \\
\text { CIL } \\
\text { COP } \\
\text { TZOO }\end{array}$ & $\begin{array}{r}<0.05 \\
0.07 \\
0.39 \\
0.19\end{array}$ & $\begin{array}{r}0.25 \pm 0.01 \\
0.21 \pm 0.01 \\
0.070 \pm 0.001 \\
0.13 \pm 0.01\end{array}$ & $\begin{array}{r}0.19 \pm 0.01 \\
0.23 \pm 0.01 \\
0.079 \pm 0.011 \\
0.14 \pm 0.01\end{array}$ \\
\hline Assimilation efficiency $\left(\% \mathrm{AE}, a_{\mathrm{c}} i_{\mathrm{c}}^{-1} \times 100 \%\right)$ & $\begin{array}{l}\text { HNP } \\
\text { CIL } \\
\text { COP } \\
\text { TZOO }\end{array}$ & $\begin{array}{l}<0.05 \\
<0.05 \\
<0.01 \\
<0.05\end{array}$ & $\begin{array}{l}33.0 \pm 3.6 \\
68.9 \pm 9.1 \\
40.9 \pm 5.7 \\
46.4 \pm 5.3\end{array}$ & $\begin{array}{l}21.6 \pm 1.2 \\
28.5 \pm 3.6 \\
11.6 \pm 3.7 \\
20.4 \pm 3.0\end{array}$ \\
\hline Growth efficiency ( $\left.\% \mathrm{GE}, g_{\mathrm{c}} i_{\mathrm{c}}^{-1} \times 100 \%\right)$ & $\begin{array}{l}\text { HNP } \\
\text { CIL } \\
\text { COP } \\
\text { TZOO }\end{array}$ & $\begin{array}{c}0.06 \\
<0.01 \\
0.37^{\mathrm{a}} \\
<0.05\end{array}$ & $\begin{array}{l}15.1 \pm 1.8 \\
40.6 \pm 4.0 \\
10.1 \pm 3.5 \\
21.9 \pm 2.0\end{array}$ & $\begin{array}{r}10.0 \pm 0.11 \\
19.1 \pm 2.0 \\
5.7 \pm 2.2 \\
12.2 \pm 1.5\end{array}$ \\
\hline
\end{tabular}


0.05, Table 6). In fact, the specific respiration of HNP decreased for high nutrient input $(p<0.05)$, whereas growth was not affected ( $p=0.26$, Table 6$)$. The assimilation efficiency was significantly reduced at high compared to normal nutrient input ( $p<0.05$ for all groups, Table 6). A comparable reduction at high nutrient input was found also for growth efficiency, but the values were only statistically significant for CIL $(\mathrm{p}<0.01$, Table 6) and TZOO ( $\mathrm{p}<0.05)$.

\section{DISCUSSION}

Our results demonstrated that both the structure and function of the planktonic food web responded dynamically and continuously to an increased rate of nutrient input. During normal low nutrient supply, all 3 functional groups of zooplankton consumed approximately the same amount of carbon and released comparable amounts of DIC, DOC and DeC. Food carbon was efficiently digested and incorporated in zooplankton biomass, indicating a relatively efficient trophic transfer of energy from primary producers. High input rate of nutrients resulted in a pronounced increase in food availability and carbon flows mediated by CIL and COP, whereas HNP and its food responded only weakly. The response in zooplankton biomasses was generally far lower than the response of the zooplankton-mediated flows. Food carbon was no longer digested and incorporated efficiently in the zooplankton, indicating a less efficient trophic transfer of energy from primary producers. This implied enhanced input rates of POC generated by defecation and mortality to deep-water and benthic communities.

\section{Validity of flow estimates}

The inverse method used to construct complete flow networks provided a relatively unbiased set of flows that fulfils mass balance requirements and physiological capabilities of the organisms. Not all these flows can be measured simultaneously, and some can hardly be measured adequately at all. The method treats the data sets of each mesocosm independently and has, in an earlier version, demonstrated a close agreement between the estimated and measured carbon flows in contrasting coastal ecosystems (Olsen et al. 2006). We obtained full rank solutions in all mesocosm communities, and the standard error of the flow estimates was as low as 0.1 to $6 \%$ of the means.

Additional systematic uncertainty of the flow estimates is related to the trophic structure (Fig. 1) and the defined constraints (Table 3). The number of components and flows should be kept to a minimum, yet our flow network is an oversimplification of the real world. It provides, however, a fair representation of the main carbon flows of the planktonic food web of coastal waters. Modifications thoroughly considered, but not implemented, were to allow CIL to feed with relatively low efficiency on picocyanobacteria (APP), to allow nano- and microautotrophs to die and form $\mathrm{DeC}$, and to introduce a fifth level in the generic food web that fed on COP (i.e. Hydromedusa; Gismervik et al. 2002, Stibor \& Tokle 2003). One modification of the original flow network had to be implemented. In the interactive process of establishing a generic flow network structure, high rank solutions were only obtained when the heterotrophic bacteria were allowed to release DOC back to the water (Fig. 1). This flow was therefore included, and it reflects bacterial lysis, by virus infection or another mechanism. The same conclusion was made for an experiment in the Baltic Sea (R. Lignell pers. comm.).

It is normally difficult to predict the effects of modifying the structure of the flow network, but DeC formation through ANP and AMP mortality would most likely have resulted in reduced estimates of feeding and DeC release flows (e.g. sloppy feeding, defecation, mortality) of COP and CIL at the highest nutrient input rates. DeC release from zooplankton was the only source of the ambient DeC pool, and its sink is sedimentation. This means that DeC release from zooplankton alone must balance the ambient DeC pool and its losses through sedimentation (Fig. 9). In order to maintain the mass balance, the model will predict an increase in zooplankton ingestion and $\mathrm{DeC}$ release. If, alternatively, ANP and AMP were allowed to die and sediment directly, this might have reduced the estimated ingestion and DeC release at high nutrient input. The specific ingestion rates obtained in Mesocosm 7 for CIL $\left(3.4 \mathrm{~d}^{-1} ; i_{\mathrm{C}}\right.$ biomass $^{-1}$, Table 5) and COP $\left(2.3 \mathrm{~d}^{-1}\right.$, Table 5) were, however, not particularly high (e.g. Thompson et al. 1994, Gismervik 2005). We still suggest, however, that ingestion and DeC release may both be overestimated in Mesocosm 7 (cf. Fig. 7, reduced $\mathrm{AE}$ and $\mathrm{GE}$ for Mesocosm 7), and we present our conclusions with this in mind.

The constraining windows for the flows used during inverse modelling were maintained broad, in order not to affect the flow estimates too much (Table 3). The estimated flows were affected by the constraints only in a few cases. The respiration rates and GE levelled off at the lower constraint value for HNP at high nutrient input and for COP in Mesocosm 7. The constraining window for specific ingestion rate of COP was set at 0 to $2 \mathrm{~d}^{-1}$ for each food component of COP, which allow a theoretical maximum ingestion rate of $8 \mathrm{~d}^{-1}$ during modelling. High estimates of ingestion rates could easily have been mitigated by introducing a 
more strict upper constraint for total feeding, this as an alternative of modifying the flow network as discussed above. A modification of the flow structure would be better than reducing the constraining window for total ingestion if the latter modification resulted in feeding flow estimates accreting at the upper constraint value. Both modifications are, however, candidates for later optional revisions of the model. The ultimate quality criteria will be the rank of the solutions produced by the model and its ability to predict measured rates, if, ultimately, there is any solution at all.

\section{Undisturbed summer situation}

A major characteristic of the normal, undisturbed situation of NE Atlantic coastal water in central Norway

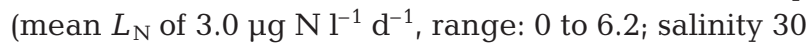
to $32 \mathrm{ppt} 15$ to $16^{\circ} \mathrm{C}$ ) was that all 3 functional groups of zooplankton consumed approximately the same amount of carbon and released comparable amounts of DIC, DOC and DeC (Figs. 8 \& 9). The losses through sedimentation from the DeC pool were relatively low (10 $\mu \mathrm{g} \mathrm{C}^{-1} \mathrm{~d}^{-1}$, range: 2 to 25 ), corresponding to $16 \%$ of GPP and $27 \%$ of total zooplankton feeding. The consumption of autotrophs by the zooplankton was $46 \%$ of GPP, whereas the total carbon feeding corresponded to $65 \%$ of GPP. The autotrophic food component was accordingly $70 \pm 3 \%$ for the zooplankton community, with the lowest autotrophic component for COP (60 \pm $6 \%)$, the intermediate for HNP $(65 \pm 2 \%)$ and the highest for CIL ( $85 \pm 5 \%)$. The autotrophic food was accordingly more important than the heterotrophic, but heterotrophic flows were important enough to conclude that carbon was allocated to higher levels through a web and not through 3 parallel food chains driven by primary production (Fig. 9).

The mean specific growth rates of the zooplankton groups at normal nutrient input (Table 6) were representative for a food concentration of around $100 \mu \mathrm{g} \mathrm{C}$ $\mathrm{l}^{-1}$ for all zooplankton groups (Fig. 3E). The growth rates may seem low, but both HNP and CIL rates agree quite well if compared to functional growth responses reported for heterotrophic nanoflagellates (Mohapatra \& Fukami 2004) and large strombidiids (Gismervik 2005). Our rates were lower than the maximum specific growth rates reported. This is to be expected, because our values represented the average growth rate for the $18 \mathrm{~d}$ period at an average food concentration well below saturation for the dominating organisms in both HNP and CIL. The average specific growth rate of COP, dominated by Acartia spp., Centropages spp., Temora longicornis and Oithona sp. at low nutrient input, was also relatively low compared to the growth capability (Hirst et al. 2003). Again the long

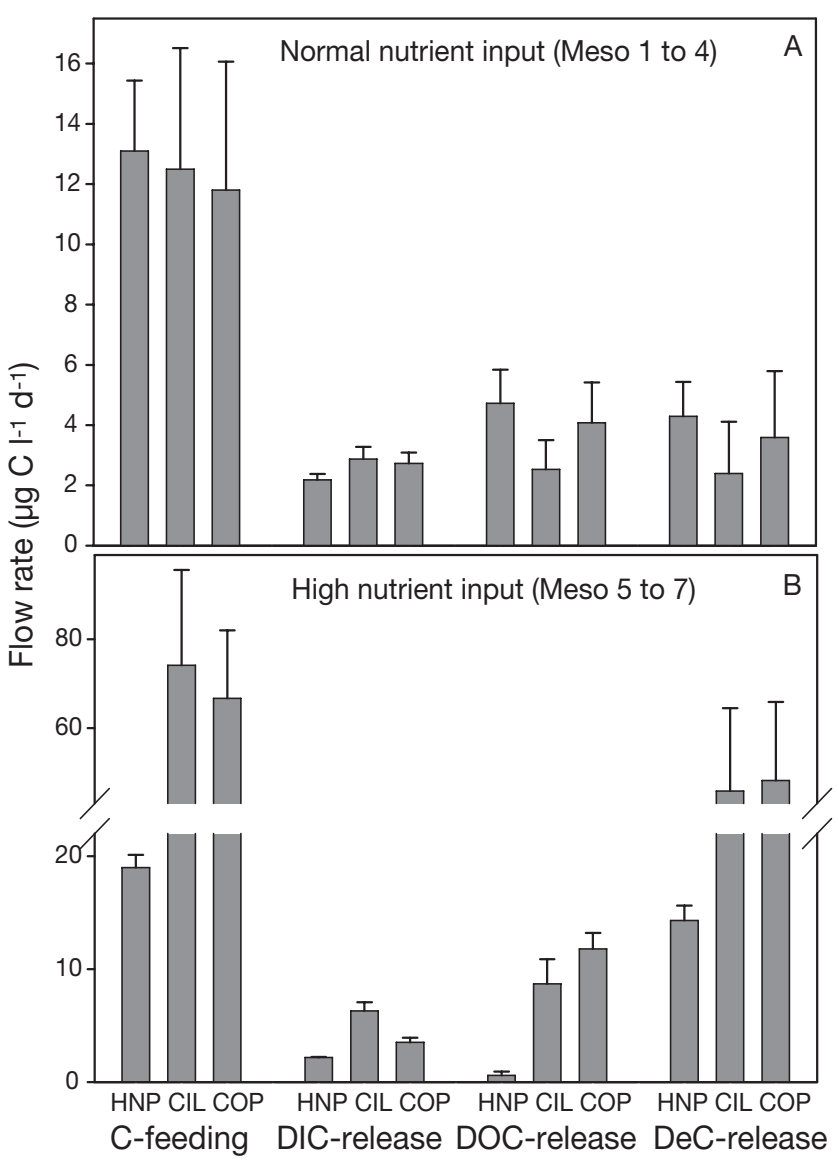

Fig. 8. Mean carbon feeding and release rates for: (A) a normal summer situation in NE Atlantic coastal waters and (B) during conditions of high nutrient input. Meso: mesocosmi other abbreviations, see Tables $2 \& 3$

period and the low food concentration may help explain this, as may the fact that copepods did not respond to the nutrient input before Day 11 (Fig. 3C and Gismervik et al. 2002).

There was generally good agreement between the processes of ingestion, respiration, assimilation, growth and reproduction, and the release of carbon through sloppy feeding, defecation, excretion and mortality. This was expressed through mean AEs in the range of 33 to $69 \%$ and GEs in the range of 10 to $41 \%$ for the zooplankton groups under normal nutrient supply. CIL showed the highest efficiencies of both assimilation and growth, whereas HNP showed the lowest $\mathrm{AE}$, and $\mathrm{COP}$, the lowest GE. The overall average AE and GE for the zooplankton community representative of the $18 \mathrm{~d}$ period were $46 \pm 5$ and $22 \pm 2 \%$, respectively. GE values were, throughout, in agreement with published values for ciliates, copepods (Straile 1997) and heterotrophic nanoflagellates (Ishigaki \& Sleigh 2001). It should be noted that HNP exhibited low carbon assimilation efficiencies, although the group 

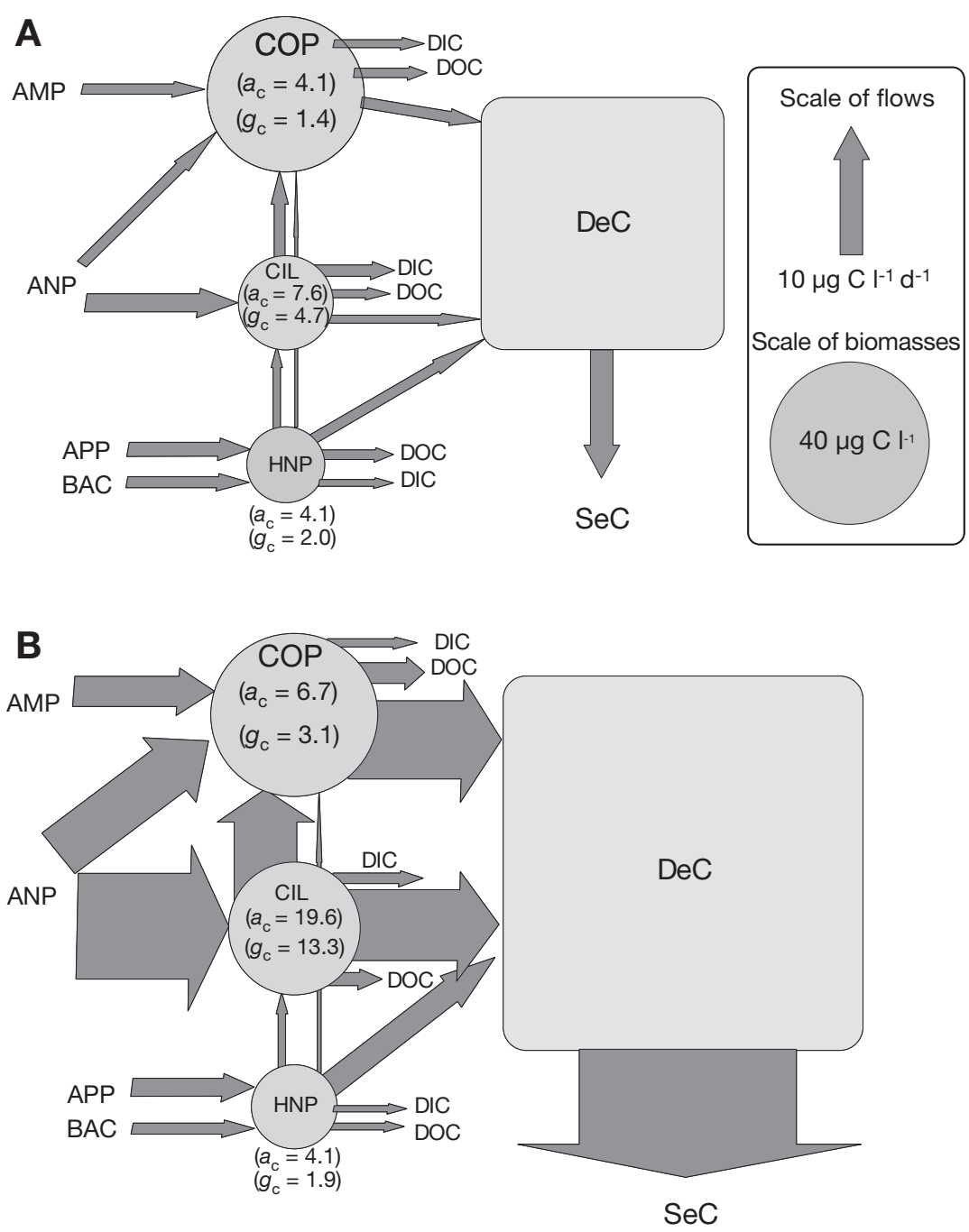

Fig. 9. Schematic view of carbon flow networks in NE Atlantic coastal waters during: (A) a normal summer situation in NE Atlantic coastal waters (mean nitrogen loading rate $\left[L_{\mathrm{N}}\right]=2.9 \pm 1.3 \mu \mathrm{g} \mathrm{N} \mathrm{l}^{-1} \mathrm{~d}^{-1}$; mean GPP $=57 \pm 18 \mu \mathrm{g} \mathrm{Cl}^{-1}$ $\mathrm{d}^{-1}$ ) and (B) conditions of high nutrient input (mean $L_{\mathrm{N}}=19.5 \pm 5.9 \mu \mathrm{g} \mathrm{N} \mathrm{l}^{-1} \mathrm{~d}^{-1}$; mean GPP $=282 \pm 72 \mu \mathrm{g} \mathrm{C}^{-1} \mathrm{~d}^{-1}$ ). $a_{\mathrm{c}}$ : assimilation; $g_{\mathrm{c}}$ : growth and reproduction ( $\mu \mathrm{g} \mathrm{C}^{-1} \mathrm{~d}^{-1}$; Table 5); GPP: gross primary production; DeC: detrital C; SeC: sedimentary $\mathrm{C}$; other abbreviations, see Table 2

appeared to be carbon or energy limited. This may suggest that its prokaryotic food is less digestible than the eukaryotic algal and protist food of CIL and COP, in agreement with the finding that the main bulk of dissolved organic nitrogen consists largely of refractory biopolymers like peptidoglycan remnants from bacterial cell walls (McCarthy et al. 1998).

The zooplankton community released $29 \pm 8 \mu \mathrm{g} \mathrm{Cl}^{-1}$ $\mathrm{d}^{-1}$ during normal nutrient supply, corresponding to $78 \%$ of carbon ingestion and $51 \%$ of the GPP. DOC and $\mathrm{DeC}$ were released in proportions of $30 \pm 3 \%$ (18 to $35 \%$, range for groups) and $24 \pm 6 \%$ (range: 13 to $32 \%$ ) of carbon ingestion, respectively. This means that $54 \%$ of the ingested carbon was lost as organic carbon to water and sediments. The carbon loss rate is a dynamic variable dependent on food quantity and quality, environmental conditions and the characteristics and state of the predator. The rates of DOC release were well within the range reported for protozoans and mesozooplankton by Nagata (2000). The release rate of $\mathrm{DeC}$ is best evaluated based on the assimilation efficiencies, which seem to be reliable (Table 6 and Nagata 2000).

The zooplankton generally counteracted reduced food availability by increasing the $\mathrm{AE}$ and GE with decreasing food availability (Fig. 7) (Straile 1997). Unlike the AE, which increases steadily, GE was reduced for all groups also during severe starvation (Mesocosm 1). This suggests the existence of a lower critical food level below which starvation becomes too severe to maintain a high allocation rate of energy into growth and reproduction. Below that point, the energy acquisition cannot any longer be maintained by increasing assimilation and growth efficiencies; the maximum assimilation efficiency of the given food source has then been reached.

Natural mortality of zooplankton is accounted for in DeC losses because dead individuals and their remains will be a component of the sedimentation flow from $\mathrm{DeC}$ to $\mathrm{SeC}$ (sedimentary C). Dead individuals from COP will not be included in the ambient DeC component, only in the flow. Our flow network structure did not include a predation flow component from COP to higher levels, even though the hydromedusae Sarsia sp. was found in the samples (Gismervik et al. 2002). Stibor \& Tokle (2003) found that Sarsia sp. was capable of ingesting copepods at a high rate, and rough estimates of their predation on copepods is comparable to the net copepod growth rate towards the end of the experiment $\left(g_{\mathrm{c}}\right.$, Table 5 , Fig. 9A). The implication of this for other estimated flows cannot easily be deduced, but we suggest that introduction of a fifth predatory component might have increased both assimilation and growth efficiencies, as well as the specific growth rate of COP. The impacts of this on ingestion and $\mathrm{DeC}$ release rates are less predictable, but also less important. 


\section{Situation of high nutrient input}

The characteristic responses of the coastal zooplankton food web in NE Atlantic coastal waters at high nutrient input (mean $L_{\mathrm{N}}$ of $19.5 \mu \mathrm{g} \mathrm{N}^{-1} \mathrm{~d}^{-1}$, range: 10.5 to 30.8 ; salinity 30 to $32 \mathrm{ppt}^{2} 15$ to $16^{\circ} \mathrm{C}$ ) are probably not quantitatively unique or reproducible in the same way as the characteristics for low to normal nutrient supply. The main lessons learned were that high nutrient input resulted in a pronounced increase in some zooplankton-mediated carbon flows and that the response in zooplankton biomass was far lower (Figs. 8B \& 9B). More precisely, the strongest responding flows were carbon ingestion and release of $\mathrm{DeC}$ by CIL and COP. Both these zooplankton groups also showed positive responses in assimilation and growth rates $\left(a_{\mathrm{c}}\right.$ and $g_{\mathrm{c} i}$ Fig. 9, Table 6). On the other hand, both groups showed only a moderate increase in biomass, which was statistically significant only for CIL $(p<0.05)$. Some HNP-mediated flows responded more than their biomass did, although far more moderately than for CIL and COP. This was, as mentioned, in agreement with the fact that the concentration and production of food for HNP was stimulated only a little by increased nutrient input.

COP showed a clear optimum in biomass and some carbon flows for the intermediate range of nutrient addition. Diatoms, suggested to be inadequate as the only food source for many copepods (Nejstgaard et al. 2001), were almost completely dominant at high nutrient input (Fig. 3F). Diatoms do not, for example, contain significant amounts of docosahexaenoic acid (DHA, 22:6n-3) (Reitan et al. 1994), which is the most important essential fatty acid in the cell membranes of coastal copepods (Evjemo et al. 2003). This essential fatty acid is crucial for de novo biomass synthesis, which is particularly important for reproduction of copepods (Arendt et al. 2005). Many diatoms may also produce aldehydes, which appear to inhibit growth and reproduction of copepods (Ianora et al. 2003). Finally, it may be important that Rhizosolenia fragilissima and colonies of Skeletonema costatum, the dominant species at high nutrient input, are both poorly available as prey for grazing zooplankton, because of their shape. The reduced biomass of COP is nevertheless a strong sign of inadequate food quality — be it the shape, optional toxic components, or inadequate nutritional composition of the phytoplankton prey. Because diatoms very often dominate temporary summer and autumn blooms in undisturbed NE Atlantic coastal water, we suggest that the high rate of nutrient input to coastal waters may generally inhibit the growth and reproduction of copepods.

We found a gradual reduction in assimilation and growth efficiencies with increasing food availability
(Fig. 7), and the mean AE was significantly lower for all zooplankton groups at high compared to low or normal nutrient input ( $p<0.05$, Table 6). The differences in mean GE were not always statistically significant, mainly because of the reduced GE at severe starvation (Fig. 7B). Reduced AE at high food concentration is in agreement with an established model (Jumars et al. 1989), whereby assimilation is maximised through a changing retention time of the food in the digestive system. Our results supported that model, because both assimilation rate and incorporation rate of carbon (Table 5) increased as GPP increased, whereas AE and GE decreased in CIL and COP (not in Mesocosm 7 for COP). The pattern of reduced $\mathrm{AE}$ and $\mathrm{GE}$ with increasing food availability in both herbivore and carnivore zooplankton is apparent from textbooks on oceanography. The mechanism for protozoans may be different, as they digest food in food vacuoles and not in a gut (Nagata 2000), but reduced assimilation and growth efficiencies seem nevertheless to be the general implication of high food availability.

Regardless of which mechanisms are involved, a reduced $\mathrm{AE}$ implies that the zooplankton will release a higher share of their ingested carbon as DOC and $\mathrm{DeC}$, which both represent food for other organisms. If high nutrient input stimulates detritus particle formation by zooplankton in an accelerating mode, this will affect carbon sedimentation flows non-linearly (Wassmann 1998) and boost heterotrophs in deep-water and benthic communities. This carbon source may particularly stimulate invertebrate predators like jellyfish residing in aphotic waters (Aksnes et al. 2004) and benthic animals like blue mussels in more shallow waters. High nutrient input will most likely also result in increased sedimentation of phytoplankton after blooming events. The zooplankton will generally amplify this signal and strengthen the potential link between coastal eutrophication and increased abundance of jellyfish.

Acknowledgements. The experimental work was undertaken by the Norwegian partners in COMWEB comparative analysis of food webs based on flow networks, a project of the European Land-Ocean Interaction Studies Programme (ELOISE) that was funded by the EU Marine Science and Technology Programme (MAST3-CT96-0052). The Research Council of Norway contributed to the final scientific treatment and publishing. The comprehensive results from the present study are attributable to the hard work of all the enthusiastic project participants involved in the experiments carried out in Hopavågen, central Norway, in August/September 1997, and in particular to the EU partners that took part and the hard working staff at Trondhjem Biological Station. Thanks to IMEDEA (Institut Mediterrani d'Estudis Avançats, Mallorca, Spain) and colleagues there for kindly allowing the first author to work out this paper in a peaceful atmosphere. 


\section{LITERATURE CITED}

Aksnes DL, Nejstgaard J, Sædberg E, Sørnes T (2004) Optical control of fish and zooplankton populations. Limnol Oceanogr 49:233-238

Arendt KE, Jónasdóttir SH, Hansen PJ, Gärtner S (2005) Effects of dietary fatty acids on the reproductive success of the calanoid copepod Temora longicornis. Mar Biol 146: 513-530

Azam F, Fenchel T, Field JG, Gray JS, Meyerreil LA, Thingstad TF (1983) The ecological role of water-column microbes in the sea. Mar Ecol Prog Ser 10:257-263

Bell RT (1983) Estimating production of heterotrophic bacterioplankton via incorporation of tritiated thymidine. In: Kemp PF, Sherr BF, Sherr EB, Cole JJ (eds) Handbook of methods in aquatic microbial ecology. Lewis Publishers, Boca Raton, FL, p 495-504

Berggreen U, Hansen B, Kiørboe T (1988) Food size spectra, ingestion and growth of the copepod Acartia tonsa during development: implications for determination of copepod production. Mar Biol 99:341-352

Booth BC (1993) Estimating cell concentrations and biomass of autotrophic plankton using microscopy. In: Kemp PF, Sherr BF, Sherr EB, Cole JJ (eds) Handbook of methods in aquatic microbial ecology. Lewis Publishers, Boca Raton, FL, p 199-205

Børsheim KY, Bratbak G (1987) Cell volume to cell carbon conversion factors for a bacterivorous Monas sp. enriched from seawater. Mar Ecol Prog Ser 36:171-175

Cloern JE (2001) Our evolving conceptual model of the coastal eutrophication problem. Mar Ecol Prog Ser 210: 223-253

del Giorgio PA, Cole JJ (1998) Bacterial growth efficiency in aquatic systems. Annu Rev Ecol Syst 29:503-541

Evjemo JO, Reitan KI, Olsen Y (2003) Copepods as live food organisms in the larval rearing of halibut larvae (Hippoglossus hippoglossus L.) with special emphasis on the nutritional value. Aquaculture 227:191-210

Fenchel T (1982) Ecology of heterotrophic microflagellates. IV. Quantitative occurrence and importance as bacterial consumers. Mar Ecol Prog Ser 9:35-42

Gismervik I (1997) Implications of zooplankton stoichiometry on distribution of $\mathrm{N}$ and $\mathrm{P}$ among planktonic size fractions. J Plankton Res 19:343-356

Gismervik I (2005) Numerical and functional responses of choreo- and oligotrich planktonic ciliates. Aquat Microb Ecol 40:163-173

Gismervik I, Andersen T, Vadstein O (1996) Pelagic food webs and eutrophication of coastal waters: impact of grazers on algal development. Mar Pollut Bull 33:22-35

Gismervik I, Olsen Y, Vadstein O (2002) Micro- and mesozooplankton response to enhanced nutrient input-a mesocosm study. Hydrobiologia 484:75-87

Grasshoff K, Ehrhardt M, Kremling K (1983) Methods of seawater analysis. Verlag Chemie, Basel

Hirst AG, Roff JC, Lampitt RS (2003) A synthesis of growth rates in marine epipelagic invertebrate zooplankton. Adv Mar Biol 44:1-142

Ianora A, Poulet SA, Miralto A (2003) The effects of diatoms on copepod reproduction: a review. Phycologia 42:351-363

Ishigaki T, Sleigh MA (2001) Grazing characteristics and growth efficiencies at two different temperatures for three nanoflagellates fed with Vibrio bacteria at three different concentrations. Microb Ecol 41:264-271

Jackson GA, Eldridge PE (1992) Food web analysis of a planktonic system off southern California. Prog Oceanogr 30:223-251
Jumars PA, Penry DL, Baross JA, Perry MJ, Frost BW (1989) Closing the microbial loop-dissolved carbon pathway to heterotrophic bacteria from incomplete ingestion, digestion and absorption in animals. Deep-Sea Res 36:483-495

Kiørboe T, Sabatini M (1994) Reproductive and life cycle strategies in egg-carrying cyclopoid and free-spawning calanoid copepods. J Plankton Res 16:1353-1366

Kiørboe T, Sabatini M (1995) Scaling of fecundity, growth and development in marine planktonic copepods. Mar Ecol Prog Ser 120:285-298

Lyche A, Andersen T, Christoffersen K, Hessen DO, Berger Hansen PH, Klyssner A (1996) Mesocosm tracer studies. I. Zooplankton as sources and sinks in the pelagic phosphorus cycle. Limnol Oceanogr 41:460-474

McCarthy M, Hedges JI, Benner R (1998) Major bacterial contribution to marine organic nitrogen. Science 281:231-234

Mohapatra BR, Fukami K (2004) Comparison of the numerical grazing response of two marine heterotrophic nanoflagellates fed with different bacteria. J Sea Res 52:99-107

Montagnes DJS (1996) Growth responses of planktonic ciliates in the genera Strobilidium and Strombidium. Mar Ecol Prog Ser 130:241-254

Nagata T (2000) Production mechanisms of dissolved organic matter. In: Kirchman DL (ed) Microbial ecology of the ocean. Wiley-Liss, New York, p 121-152

Nakamura Y, Suzuki K, Suzuki SY, Hiromi J (1997) Production of Oikopleura dioica (Appendicularia) following a picoplankton 'bloom' in a eutrophic coastal area. J Plankton Res 19:113-124

Nejstgaard JC, Hygum BH, Naustvoll LJ, Båmstedt U (2001) Zooplankton growth, diet and reproductive success compared in simultaneous diatom- and flagellate-microzooplankton-dominated plankton blooms. Mar Ecol Prog Ser 221:77-91

Olsen Y, Agusti S, Andersen T, Duarte CM and 13 others (2006) A comparative study of planktonic responses to experimental nutrient addition to European coastal waters. Limnol Oceanogr 51:488-503

Porter KG, Feig YS (1980) The use of DAPI for identification and enumeration of bacteria and blue-green algae. Limnol Oceanogr 25:943-948

Putt M, Stoecker DK (1989) An experimentally determined carbon:volume ratio for marine 'oligotrichous' ciliates from estuarine and coastal waters. Limnol Oceanogr 34: 1097-1103

Reitan KI, Rainuzzo JR, Olsen Y (1994) Effect of nutrient limitation on fatty acid and lipid content of marine microalgae. J Phycol 30:972-979

Sabatini M, Kiørboe T (1994) Egg production, growth and development of the cyclopoid copepod Oithona similis. J Plankton Res 16:1329-1351

Sherr EB, Sherr BF (2002) Significance of predation by protists in aquatic microbial food webs. Antonie Leeuwenhoek Int J Gen Mol Microbiol 81:293-308

Sommer U, Stibor H (2002) Copepoda-Cladocera-Tunicata: the role of three major mesozooplankton groups in pelagic food webs. Ecol Res 17:161-174

Stibor H, Tokle N (2003) Feeding and asexual reproduction of the jellyfish Sarsia gemmifera in response to resource enrichment. Oecologia 135:202-208

Stibor H, Vadstein O, Diehl S, Gelzleichter A and 10 others (2004) Copepods act as a switch between alternative trophic cascades in marine pelagic food webs. Ecol Lett 7 : 321-328

Stone L, Berman T, Bonner R, Barry S, Weeks SW (1993) Lake Kinneret: a seasonal model for carbon flux through the planktonic biota. Limnol Oceanogr 38:1680-1695 
Straile D (1997) Gross growth efficiencies of protozoan and metazoan zooplankton and their dependence on food concentration, predator-prey weight ratio, and taxonomic group. Limnol Oceanogr 42:1375-1385

Strathmann RR (1967) Estimating the organic carbon content of phytoplankton from cell volume or plasma volume. Limnol Oceanogr 12:411-418

Tanaka T, Rassoulzadegan F (2002) Full-depth profile (0-2000 $\mathrm{m})$ of bacteria, heterotrophic nanoflagellates and ciliates in the NW Mediterranean Sea: vertical partitioning of microbial trophic structures. Deep-Sea Res II 29:2093-2107

Thompson AM, Durbin EG, Durbin AG (1994) Seasonal changes in maximum ingestion rate of Acartia tonsa in Narragansett Bay, Rhode Island, USA. Mar Ecol Prog Ser 108:91-105

Vadstein O, Olsen Y (1989) Chemical composition and $\mathrm{PO}_{4}$ uptake of limnetic bacterial communities cultured in chemostat under P limitation. Limnol Oceanogr 34:939-946

Editorial responsibility: Howard Browman (Associate Editorin-Chief), Storebø, Norway
Vadstein O, Stibor H, Lippert B, Løseth K, Roederer W, Sundt-Hansen LE, Olsen Y (2004) Moderate increase in the biomass of omnivorous copepods may release grazing control of planktonic algae. Mar Ecol Prog Ser 270: 199-207

Vézina AF (1989) Construction of flow networks using inverse methods. In: Wulff F, Field JG, Mann KH (eds) Network analysis in marine ecology. Methods and applications. Springer Verlag, Heidelberg, p 62-81

Vézina AF, Pace ML (1994) An inverse analysis of plankton food webs in experimental lakes. Can J Fish Aquat Sci 51: 2034-2044

Vézina AF, Platt T (1988) Food web dynamics in the ocean. I. Best-estimates of flow networks using inverse methods. Mar Ecol Prog Ser 42:269-287

Wassmann P (1998) Retention versus export food chains: processes controlling sinking loss from marine pelagic systems. Hydrobiologia 363:29-57

Submitted: February 13, 2006; Accepted: June 25, 2006 Proofs received from author(s): January 29, 2007 